\title{
Effect of manganese substitution on the structure and activity of iron titanate catalyst for the selective catalytic reduction of $\mathrm{NO}$ with $\mathrm{NH}_{3}$
}

\author{
Fudong Liu, Hong He*, Yun Ding, Changbin Zhang \\ State Key Laboratory of Environmental Chemistry and Ecotoxicology, Research Center for Eco-Environmental Sciences, Chinese Academy of Sciences, Beijing 100085, PR China
}

\section{A R T I C L E I N F O}

\section{Article history:}

Received 9 June 2009

Received in revised form 10 September 2009

Accepted 22 September 2009

Available online 25 September 2009

\section{Keywords:}

Selective catalytic reduction

Iron titanate catalyst

Mn substitution amounts

Low temperature activity

Redox behavior

\begin{abstract}
A B S T R A C T
Selective catalytic reduction (SCR) of $\mathrm{NO}$ with $\mathrm{NH}_{3}$ over manganese substituted iron titanate catalysts was fully studied. The low temperature SCR activity was greatly enhanced when partial Fe was substituted by $\mathrm{Mn}$, although the $\mathrm{N}_{2}$ selectivity showed some decrease to a certain extent. The Mn substitution amounts showed obvious influence on the catalyst structure, redox behavior and $\mathrm{NH}_{3} / \mathrm{NO}_{x}$ adsorption ability of the catalysts. Among $\mathrm{Fe}_{a} \mathrm{Mn}_{1-a} \mathrm{TiO}_{x}(a=1,0.75,0.5,0.2,0)$ serial catalysts, $\mathrm{Fe}_{0.5} \mathrm{Mn}_{0.5} \mathrm{TiO}_{x}$ with the molar ratio of $\mathrm{Fe}: \mathrm{Mn}=1: 1$ showed the highest SCR activity, because the interaction of iron, manganese and titanium species in this catalyst led to the largest surface area and the highest porosity, the severest structural distortion and most appropriate structural disorder, the enhanced oxidative ability of manganese species, the highest mobility of lattice oxygen, the proper ratio of Brønsted acid sites and Lewis acid sites together with the enhanced $\mathrm{NO}_{x}$ adsorption capacity.
\end{abstract}

(c) 2009 Elsevier B.V. All rights reserved.

\section{Introduction}

Selective catalytic reduction (SCR) of NO with $\mathrm{NH}_{3}$ is one of the most efficient and economic technologies for the removal of nitrogen oxides $\left(\mathrm{NO}_{x}\right)$ from stationary and mobile sources, and the most widely used catalyst system is $\mathrm{V}_{2} \mathrm{O}_{5}-\mathrm{WO}_{3}\left(\mathrm{MoO}_{3}\right) / \mathrm{TiO}_{2}$ [1]. Because of some inevitable disadvantages in practical application, such as the narrow operation temperature window [2], high conversion of $\mathrm{SO}_{2}$ to $\mathrm{SO}_{3}$ at high temperatures [3] and the toxicity of vanadium pentoxide to environment and human health [4], more and more researchers are focusing on the development of new SCR catalysts. In our previous study [5,6], we have developed an environmentally friendly novel iron titanate catalyst in crystallite phase with specific $\mathrm{Fe}-\mathrm{O}-\mathrm{Ti}$ structure, which showed excellent SCR activity, $\mathrm{N}_{2}$ selectivity and $\mathrm{H}_{2} \mathrm{O} / \mathrm{SO}_{2}$ durability in the medium temperature range. However, the catalytic activity was not high enough for the application in denitrogenation of exhaust gas with low temperature, such as the flue gas after dust removal and desulfurization from coal-fired power plants and the exhaust gas from diesel engines in cold-start process. Therefore, it is very necessary to modify this iron titanate catalyst to improve the low temperature activity, which is crucial for the practical utilization.

Manganese oxides usually show good SCR activity in the low temperature range, such as pure $\mathrm{MnO}_{x}[7,8], \mathrm{MnO}_{x}$ loaded on $\mathrm{TiO}_{2} /$

\footnotetext{
* Corresponding author at: P.O. Box 2871, 18 Shuangqing Road, Haidian District, Beijing 100085, PR China. Tel.: +86 10 62849123; fax: +86 1062849123.

E-mail address: honghe@rcees.ac.cn (H. He).
}

$\mathrm{Al}_{2} \mathrm{O}_{3} / \mathrm{SiO}_{2} / \mathrm{AC}$ (activated carbon) [9-12] and $\mathrm{Mn}-\mathrm{Ce}, \mathrm{Mn}-\mathrm{Cu}$ mixed oxides [13-15]. Previous studies showed that in Fecontaining SCR catalysts, the introduction of Mn could obviously enhance the low temperature activity $[16,17]$, probably due to the synergistic effect between iron and manganese species. It was reported that the introduction of lanthanide elements (such as La, Ce and $\mathrm{Pr}$ ) and the third main group element In could also improve the activity, stability or $\mathrm{SO}_{2}$ durability of the SCR catalysts using $\mathrm{NH}_{3}$ or hydrocarbons as reducing agent [18-22]. Therefore, based on our iron titanate catalyst, we can also substitute partial Fe by other elements to adjust its physicochemical properties, expecting to enhance the low temperature SCR activity.

In this paper, five kinds of elements including La, Ce, Pr, In and Mn were introduced into the iron titanate catalyst, among which Mn showed the best promoting effect. Based on this result, we further investigated the influence of Mn substitution amounts on the catalyst structure and catalytic activity using various characterization methods. The structural properties were characterized using $\mathrm{N}_{2}$ physisorption, powder X-ray diffraction (XRD) and X-ray absorption fine structure (XAFS) methods. Then, X-ray photoelectron spectra (XPS) and $\mathrm{H}_{2}$-temperature programmed reduction $\left(\mathrm{H}_{2}\right.$-TPR) were conducted to evaluate the variation of redox properties during the substitution process. Finally, temperature programmed desorption of $\mathrm{NH}_{3}$ and $\mathrm{NO}_{x}\left(\mathrm{NH}_{3}\right.$-TPD and $\mathrm{NO}_{x}$-TPD) together with in situ diffuse reflectance infrared Fourier transform spectroscopy (in situ DRIFTS) of $\mathrm{NH}_{3}$ and $\mathrm{NO}_{x}$ adsorption was carried out to reveal the evolution of adsorption ability of reactants, which is important for the SCR reaction. The promoting mechanism of $\mathrm{Mn}$ on the low temperature SCR activity of iron titanate catalyst was proposed accordingly. 


\section{Experimental}

\subsection{Catalyst synthesis and activity test}

$\mathrm{Fe}_{0.9} \mathrm{M}_{0.1} \mathrm{TiO}_{x}(\mathrm{M}=\mathrm{La}, \mathrm{Ce}, \mathrm{Pr}, \mathrm{In}, \mathrm{Mn})$ and $\mathrm{Fe}_{a} \mathrm{Mn}_{1-a} \mathrm{TiO}_{x}$ with different Mn substitution amounts $(a=1,0.75,0.5,0.2,0)$ were prepared by co-precipitation method using $\mathrm{Fe}\left(\mathrm{NO}_{3}\right)_{3} \cdot 9 \mathrm{H}_{2} \mathrm{O}$, $\mathrm{Ti}\left(\mathrm{SO}_{4}\right)_{2}$, relevant metal nitrates as precursors and $\mathrm{NH}_{3} \cdot \mathrm{H}_{2} \mathrm{O}$ (25 wt\%) as precipitator. The precipitate cake was filtrated and washed using distilled water, followed by desiccation at $100{ }^{\circ} \mathrm{C}$ for $12 \mathrm{~h}$ and calcination at $400{ }^{\circ} \mathrm{C}$ for $6 \mathrm{~h}$ in air condition. Pure oxides including $\mathrm{Fe}_{2} \mathrm{O}_{3}, \mathrm{MnO}_{x}$ and $\mathrm{TiO}_{2}$ were prepared from $\mathrm{Fe}\left(\mathrm{NO}_{3}\right)_{3} \cdot 9 \mathrm{H}_{2} \mathrm{O}, \mathrm{Mn}\left(\mathrm{NO}_{3}\right)_{2}$ and $\mathrm{Ti}\left(\mathrm{SO}_{4}\right)_{2}$ using the same precipitation method for the comparison of SCR activity. The state-of-theart SCR catalyst $4.5 \mathrm{wt} \% \mathrm{~V}_{2} \mathrm{O}_{5}-10 \mathrm{wt} \% \mathrm{WO}_{3} / \mathrm{TiO}_{2}$ was also prepared using conventional wet impregnation method as reference in the SCR activity test.

The $\mathrm{NH}_{3}-\mathrm{SCR}$, NO oxidation and $\mathrm{NH}_{3}$ oxidation tests were carried out over $0.6 \mathrm{ml}$ catalysts (ca. $200-350 \mathrm{mg}$ due to the different catalyst densities) in a fixed-bed quartz tube reactor and the reaction conditions were as follows: $500 \mathrm{ppm} \mathrm{NO}$ and (or) $500 \mathrm{ppm} \mathrm{NH}_{3}, 5$ vol.\% $\mathrm{O}_{2}, 1000 \mathrm{ppm} \mathrm{CO}$ (when used), 5 vol.\% $\mathrm{CO}_{2}$ (when used), 5 vol.\% $\mathrm{H}_{2} \mathrm{O}$ (when used), $\mathrm{N}_{2}$ balance and gas hourly space velocity $(\mathrm{GHSV})=50000 \mathrm{~h}^{-1}$. The effluent gas was analyzed using an FTIR spectrometer (Nicolet Nexus 670) equipped with a heated, low volume multiple-path gas cell $(2 \mathrm{~m})$. $\mathrm{NO}_{x}$ conversion $\left(X_{\mathrm{NO}_{x}}\right)$ and $\mathrm{N}_{2}$ selectivity $\left(\mathrm{S}_{\mathrm{N}_{2}}\right)$ were calculated as follows:

$X_{\mathrm{NO}_{x}}=\left(1-\frac{\left[\mathrm{NO}_{x}\right]_{\mathrm{out}}}{\left[\mathrm{NO}_{x}\right]_{\text {in }}}\right) \times 100 \%$ with $\left[\mathrm{NO}_{x}\right]=[\mathrm{NO}]+\left[\mathrm{NO}_{2}\right]$

$S_{\mathrm{N}_{2}}=\frac{[\mathrm{NO}]_{\text {in }}+\left[\mathrm{NH}_{3}\right]_{\text {in }}-\left[\mathrm{NO}_{2}\right]_{\text {out }}-2\left[\mathrm{~N}_{2} \mathrm{O}\right]_{\text {out }}}{[\mathrm{NO}]_{\text {in }}+\left[\mathrm{NH}_{3}\right]_{\text {in }}} \times 100 \%$

\subsection{Characterizations}

$\mathrm{N}_{2}$ adsorption-desorption isotherms were obtained at $77 \mathrm{~K}$ using a Quantachrome Autosorb-1C instrument. Prior to $\mathrm{N}_{2}$ adsorption, the samples were degassed at $300{ }^{\circ} \mathrm{C}$ for $4 \mathrm{~h}$. The surface areas were determined by BET equation in 0.05-0.35 partial pressure range. The pore volumes, average pore diameters and pore size distributions were determined by BJH method from the desorption branches of the isotherms.

Powder XRD measurements were carried out on a computerized Rigaku D/max-RB Diffractometer (Japan, $\mathrm{Cu} \mathrm{K}_{\alpha}$ as radiation resource). The data of $2 \theta$ from $10^{\circ}$ to $90^{\circ}$ were collected at $4 \% \mathrm{~min}$ with the stepsize of $0.02^{\circ}$.

XAFS experiments were implemented on U7C beamline of National Synchrotron Radiation Laboratory (NSRL), of which the storage ring was operated at $0.8 \mathrm{GeV}$ with a maximum current of $300 \mathrm{~mA}$. The hard X-ray beam was from a three-pole superconducting Wiggler with a magnetic field intensity of $6 \mathrm{~T}$. A fixedexit $\operatorname{Si}\left(\begin{array}{lll}1 & 1 & 1\end{array}\right)$ double-crystal monochromator was used to reduce the harmonic content of the monochrome beam. The incident and output beam intensities were monitored and recorded using ionization chambers filled by $\mathrm{Ar} / \mathrm{N}_{2}$. A Keithley Model 6517 Electrometer was used to collect the electron charge directly. Before XAFS measurement, the catalyst samples were crushed into fine powder above 200 mesh and coated onto transparent adhesive tapes. The XAFS spectra (X-ray absorption near-edge spectroscopy, XANES and extended X-ray absorption fine-structure spectroscopy, EXAFS) of Fe-K-edge and Mn-K-edge were recorded in transmission mode at room temperature in air condition. The collected XAFS data were calibrated according to standard $\mathrm{Fe}_{2} \mathrm{O}_{3}$ and $\mathrm{MnO}_{2}$ samples and then analyzed using Viper software package according to standard procedures [23]. During the EXAFS data processing procedure, the back-subtracted EXAFS function was firstly converted into $k$ space and weighted by $k^{3}$ in order to compensate for the diminishing amplitude because of the decay of the photoelectron wave. The Fourier transforming of the $k^{3}$-weighted EXAFS data was performed in the range of $k=2-11.01 \AA^{-1}$ for both Fe-K-edge and Mn-K-edge with a Hanning function window.

XPS were recorded on a Scanning X-ray Microprobe (PHI Quantera, ULVAC-PHI, Inc.) using $\mathrm{Al} \mathrm{K}_{\alpha}$ radiation $(1486.7 \mathrm{eV}$ ). Binding energies of Fe 2p, Mn 2p, Ti $2 p$ and $O$ 1s were calibrated using $\mathrm{C} 1 \mathrm{~s}$ peak $(\mathrm{BE}=284.8 \mathrm{eV})$ as standard.

Prior to $\mathrm{H}_{2}$-TPR experiment, the samples $(100 \mathrm{mg}$ ) were pretreated at $300{ }^{\circ} \mathrm{C}$ in a flow of $20 \mathrm{vol} . \% \mathrm{O}_{2} / \mathrm{He}(30 \mathrm{ml} / \mathrm{min})$ for $0.5 \mathrm{~h}$ and cooled down to the room temperature $\left(30^{\circ} \mathrm{C}\right)$. Then the temperature was raised linearly to $900{ }^{\circ} \mathrm{C}$ at the rate of $10^{\circ} \mathrm{C} / \mathrm{min}$ in a flow of $5 \mathrm{vol} . \% \mathrm{H}_{2} / \mathrm{Ar}(30 \mathrm{ml} / \mathrm{min})$. The $\mathrm{H}_{2}$ signal $(\mathrm{m} / \mathrm{z}=2)$ was monitored online using a quadrupole mass spectrometer (HPR20, Hiden Analytical Ltd.).

$\mathrm{NH}_{3}$-TPD and $\mathrm{NO}_{x}$-TPD were also performed using the same quadrupole mass spectrometer to record the signals of $\mathrm{NH}_{3}(\mathrm{~m} /$ $z=16$ for $\mathrm{NH}_{2}$ and $m / z=15$ for $\left.\mathrm{NH}\right)$ and $\mathrm{NO}_{x}(\mathrm{~m} / z=30$ for $\mathrm{NO}$ and $m / z=46$ for $\mathrm{NO}_{2}$ ). Prior to TPD experiments, the samples $(100 \mathrm{mg}$ ) were also pretreated at $300{ }^{\circ} \mathrm{C}$ in a flow of $20 \mathrm{vol} . \% \mathrm{O}_{2} / \mathrm{He}(30 \mathrm{ml} /$ $\min$ ) for $0.5 \mathrm{~h}$ and cooled down to the room temperature $\left(30^{\circ} \mathrm{C}\right)$. Then the samples were exposed to a flow of $2500 \mathrm{ppm} \mathrm{NH}_{3} / \mathrm{Ar}$ or $2500 \mathrm{ppm} \mathrm{NO}+10 \mathrm{vol} . \% \mathrm{O}_{2} / \mathrm{Ar}(30 \mathrm{ml} / \mathrm{min})$ at $30^{\circ} \mathrm{C}$ for $1 \mathrm{~h}$, following by Ar purge for another $1 \mathrm{~h}$. Finally, the temperature was raised to $500{ }^{\circ} \mathrm{C}$ in $\mathrm{Ar}$ flow at the rate of $10^{\circ} \mathrm{C} / \mathrm{min}$.

The in situ DRIFTS experiments of $\mathrm{NH}_{3} / \mathrm{NO}_{x}$ adsorption over $\mathrm{Fe}_{a} \mathrm{Mn}_{1-a} \mathrm{TiO}_{x}$ catalysts were performed on an FTIR spectrometer (Nicolet Nexus 670) equipped with an MCT/A detector cooled by liquid nitrogen. An in situ DRIFTS reactor cell with ZnSe window (Nexus Smart Collector) connected to a purging/adsorption gas control system was used for the $\mathrm{NH}_{3} / \mathrm{NO}_{x}$ in situ adsorption experiments. The temperature of the reactor cell was controlled precisely by an Omega programmable temperature controller. Prior to $\mathrm{NH}_{3} / \mathrm{NO}_{x}$ adsorption, the samples were pretreated at $400{ }^{\circ} \mathrm{C}$ in a flow of $20 \mathrm{vol} . \% \mathrm{O}_{2} / \mathrm{N}_{2}$ for $0.5 \mathrm{~h}$ and cooled down to $30{ }^{\circ} \mathrm{C}$. The spectra of different catalysts at $30^{\circ} \mathrm{C}$ were collected in flowing $\mathrm{N}_{2}$ and set as backgrounds, which were automatically subtracted from the final spectra after $\mathrm{NH}_{3} / \mathrm{NO}_{x}$ adsorption. Then the samples were exposed to a flow of $500 \mathrm{ppm} \mathrm{NH}_{3} / \mathrm{N}_{2}$ or $500 \mathrm{ppm} \mathrm{NO}+5 \mathrm{vol} . \% \quad \mathrm{O}_{2} / \mathrm{N}_{2}(300 \mathrm{ml} / \mathrm{min})$ at $30{ }^{\circ} \mathrm{C}$ for $1 \mathrm{~h}$, following by $\mathrm{N}_{2}$ purge for another $0.5 \mathrm{~h}$. All spectra were recorded by accumulating 100 scans with a resolution of $4 \mathrm{~cm}^{-1}$.

\section{Results and discussion}

\subsection{Catalytic performance}

3.1.1. SCR activity of $\mathrm{Fe}_{0.9} \mathrm{M}_{0.1} \mathrm{TiO}_{x}$ catalysts $(\mathrm{M}=\mathrm{La}, \mathrm{Ce}, \mathrm{Pr}, \mathrm{In}, \mathrm{Mn})$

Fig. 1 shows the $\mathrm{NO}_{x}$ conversion as a function of temperature in the $\mathrm{NH}_{3}$-SCR reaction over $\mathrm{Fe}_{0.9} \mathrm{M}_{0.1} \mathrm{TiO}_{x}$ catalysts $(\mathrm{M}=\mathrm{La}, \mathrm{Ce}, \mathrm{Pr}$, In, $\mathrm{Mn}$ ). From the results we can see that, the substitution of partial Fe with other elements could indeed influence the SCR activity of iron titanate catalyst. At temperatures below $250{ }^{\circ} \mathrm{C}$, the $\mathrm{Mn}$ and $\mathrm{Ce}$ substitutions could obviously enhance the $\mathrm{NO}_{x}$ conversions, while the $\mathrm{La}, \mathrm{Pr}$ and In substitutions decreased the $\mathrm{NO}_{x}$ conversions to a certain extent. Moreover, the Ce substitution lowered the $\mathrm{NO}_{x}$ conversion at relatively high temperatures above $300^{\circ} \mathrm{C}$, while the Mn substitution did not show such an obvious negative influence. Therefore, we chose Mn as the substitution element to carry out our further investigations, such as the effect of Mn substitution amounts on $\mathrm{NH}_{3}-\mathrm{SCR}$, $\mathrm{NO}$ oxidation and $\mathrm{NH}_{3}$ oxidation activities, together with the relationship between catalyst structure and catalytic activity. 


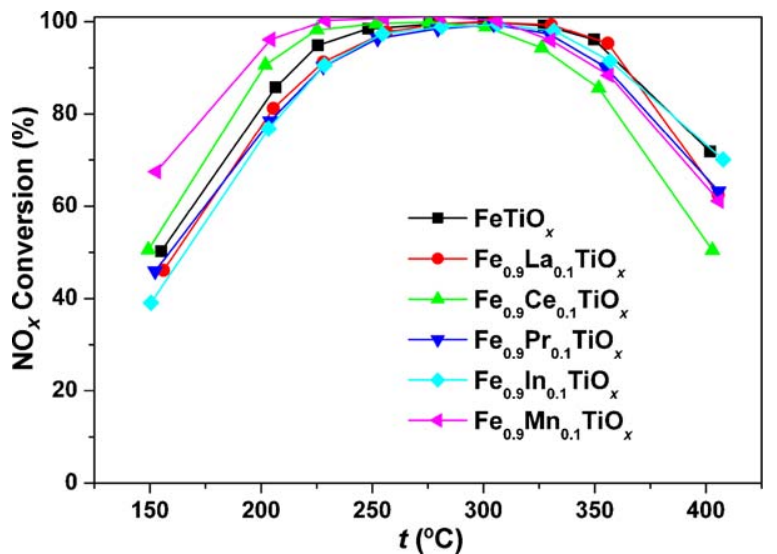

Fig. 1. $\mathrm{NO}_{x}$ conversion as a function of temperature in the $\mathrm{NH}_{3}-\mathrm{SCR}$ reaction over $\mathrm{Fe}_{0.9} \mathrm{M}_{0.1} \mathrm{TiO}_{x}$ catalysts. Reaction conditions: $[\mathrm{NO}]=\left[\mathrm{NH}_{3}\right]=500 \mathrm{ppm},\left[\mathrm{O}_{2}\right]=5 \mathrm{vol} . \%$, $\mathrm{N}_{2}$ balance, total flow rate $500 \mathrm{ml} / \mathrm{min}$ and $\mathrm{GHSV}=50000 \mathrm{~h}^{-1}$.

\subsubsection{SCR activity of $\mathrm{Fe}_{a} \mathrm{Mn} n_{1-a} \mathrm{TiO}_{x}$ catalysts}

Fig. 2A shows the results of $\mathrm{NO}_{x}$ conversion and $\mathrm{N}_{2}$ selectivity in the SCR reaction over $\mathrm{Fe}_{a} \mathrm{Mn}_{1-a} \mathrm{TiO}_{x}(a=1,0.75,0.5,0.2,0)$ catalysts and pure oxides including $\mathrm{Fe}_{2} \mathrm{O}_{3}, \mathrm{MnO}_{x}$ and $\mathrm{TiO}_{2}$ as a function of temperature from 75 to $400{ }^{\circ} \mathrm{C}$. As we can see, pure $\mathrm{TiO}_{2}$ showed no SCR activity below $350{ }^{\circ} \mathrm{C}$ and only $30 \% \mathrm{NO}_{x}$ conversion was obtained at $400{ }^{\circ} \mathrm{C}$. Pure $\mathrm{Fe}_{2} \mathrm{O}_{3}$ and $\mathrm{MnO}_{x}$ showed very narrow operation temperature windows in the high and low temperature ranges, respectively, and both of the maximum $\mathrm{NO}_{x}$ conversions could not reach $100 \%$. Furthermore, the $\mathrm{N}_{2}$ selectivity over these two samples was rather low as shown in the inserted figure. The coexistence of $\mathrm{Fe}$ and $\mathrm{Ti}$ in $\mathrm{FeTiO}_{x}$ greatly enlarged the operation temperature window and the $\mathrm{NO}_{x}$ could be completely reduced from 225 to $350{ }^{\circ} \mathrm{C}$ with high $\mathrm{N}_{2}$ selectivity. When partial Fe was substituted by $\mathrm{Mn}$, the $\mathrm{NO}_{x}$ conversions in the relatively low temperature range had an obvious increase. $\mathrm{Fe}_{0.5} \mathrm{Mn}_{0.5} \mathrm{TiO}_{x}$ with the molar ratio of $\mathrm{Fe}: \mathrm{Mn}=1: 1$ showed the best activity, over which $\mathrm{NO}_{x}$ was completely reduced at about $175{ }^{\circ} \mathrm{C}$. However, the continuing substitution of Fe by more Mn led to an activity decrease, and the $\mathrm{NO}_{x}$ conversions over $\mathrm{Fe}_{0.2} \mathrm{Mn}_{0.8} \mathrm{TiO}_{x}$ and $\mathrm{MnTiO}_{x}$ from 75 to $250{ }^{\circ} \mathrm{C}$ were even lower than that over $\mathrm{Fe}_{0.75} \mathrm{Mn}_{0.25} \mathrm{TiO}_{x}$. The apparent SCR activity at low temperatures increased in the following sequence: $\mathrm{FeTiO}_{x} \ll \mathrm{MnTiO}_{x}$ $<\mathrm{Fe}_{0.2} \mathrm{Mn}_{0.8} \mathrm{TiO}_{x}<\mathrm{Fe}_{0.75} \mathrm{Mn}_{0.25} \mathrm{TiO}_{x}<\mathrm{Fe}_{0.5} \mathrm{Mn}_{0.5} \mathrm{TiO}_{x}$. In previous study by Qi and Yang [16], they also observed that Fe-Mn/TiO catalyst with Fe:Mn = 1:1 showed the highest activity among their loaded type catalysts in the SCR reaction. This could be attributed to the strong interaction between $\mathrm{Fe}$ and $\mathrm{Mn}$ which led to high dispersion of active phases and thus the high SCR activity.

Although the substitution of Fe by $\mathrm{Mn}$ in iron titanate catalyst could enhance the SCR activity, the $\mathrm{N}_{2}$ selectivity had an obvious decrease owing to the production of $\mathrm{N}_{2} \mathrm{O}$, especially at high temperatures above $200{ }^{\circ} \mathrm{C}$. The $\mathrm{N}_{2}$ selectivity at high temperatures decreased in the following sequence: $\mathrm{FeTiO}_{x}>\mathrm{Fe}_{0.75} \mathrm{Mn}_{0.25}$ $\mathrm{TiO}_{x}>\mathrm{Fe}_{0.5} \mathrm{Mn}_{0.5} \mathrm{TiO}_{x} \approx \mathrm{Fe}_{0.2} \mathrm{Mn}_{0.8} \mathrm{TiO}_{x} \approx \mathrm{MnTiO}_{x}$. Considering the $\mathrm{NO}_{x}$ conversion and $\mathrm{N}_{2}$ selectivity, we chose $\mathrm{Fe}_{0.75} \mathrm{Mn}_{0.25} \mathrm{TiO}_{x}$ as model catalyst over which the $\mathrm{N}_{2}$ selectivity could maintain above $90 \%$ at temperatures below $300{ }^{\circ} \mathrm{C}$, to compare with the state-of-theart SCR catalysts including the traditional $\mathrm{V}_{2} \mathrm{O}_{5}-\mathrm{WO}_{3} / \mathrm{TiO}_{2}$ catalyst and $\mathrm{Fe}, \mathrm{Cu}$ exchanged zeolites. As shown in Fig. 2B, Fe/ZSM-5 [24] and Fe/HBEA [4] catalysts showed good SCR activity at relatively high temperatures, over which the maximum $\mathrm{NO} / \mathrm{NO}_{x}$ conversions were obtained above 350 and $250{ }^{\circ} \mathrm{C}$, respectively. As for our $\mathrm{Fe}_{0.75} \mathrm{Mn}_{0.25} \mathrm{TiO}_{x}$ catalyst, the low temperature SCR activity was much better than that of Fe exchanged zeolites, although the high temperature SCR activity above $300{ }^{\circ} \mathrm{C}$ showed sharp decrease resulting in a narrow operation temperature window. Remarkably,
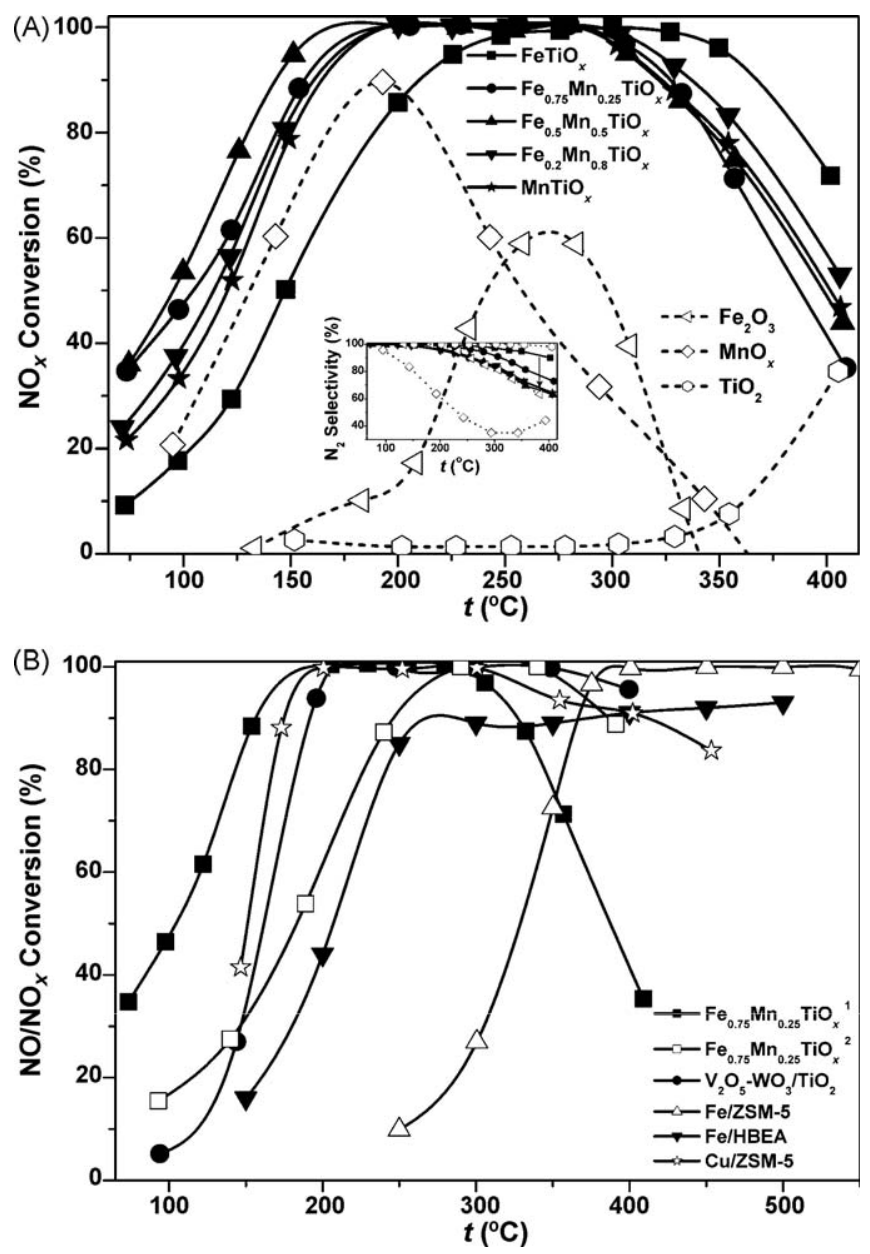

Fig. 2. (A) $\mathrm{NO}_{x}$ conversion and $\mathrm{N}_{2}$ selectivity (inserted) in the $\mathrm{NH}_{3}-\mathrm{SCR}$ reaction over $\mathrm{Fe}_{a} \mathrm{Mn}_{1-a} \mathrm{TiO}_{x}$ catalysts and pure oxides including $\mathrm{Fe}_{2} \mathrm{O}_{3}, \mathrm{MnO}_{x}$ and $\mathrm{TiO}_{2}$, reaction conditions: $[\mathrm{NO}]=\left[\mathrm{NH}_{3}\right]=500 \mathrm{ppm},\left[\mathrm{O}_{2}\right]=5 \mathrm{vol} . \%, \mathrm{~N}_{2}$ balance and $\mathrm{GHSV}=$ $50000 \mathrm{~h}^{-1}$. (B) Comparison of apparent SCR activity over $\mathrm{Fe}_{0.75} \mathrm{Mn}_{0.25} \mathrm{TiO}_{x}{ }^{1}$ (GHSV $=50000 \mathrm{~h}^{-1}$ without $\left.\mathrm{H}_{2} \mathrm{O}\right), \mathrm{Fe}_{075} \mathrm{Mn}_{0,25} \mathrm{TiO}_{x}{ }^{2}$ (GHSV $=100000 \mathrm{~h}^{-1}$ with 10 vol.\% $\mathrm{H}_{2} \mathrm{O}$ ), $4.5 \mathrm{wt} \% \mathrm{~V}_{2} \mathrm{O}_{5}-10 \mathrm{wt} \% \mathrm{WO}_{3} / \mathrm{TiO}_{2}$, Fe/ZSM-5 (NO conversion on $\mathrm{Fe}(58)-\mathrm{ZSM}-5(10)$ from Ref. [24], reaction conditions: $[\mathrm{NO}]=\left[\mathrm{NH}_{3}\right]=1000 \mathrm{ppm}$, $\left[\mathrm{O}_{2}\right]=2 \mathrm{vol} . \%$ and GHSV $\left.=46000 \mathrm{~h}^{-1}\right)$, Fe/HBEA $\left(\mathrm{NO}_{x}\right.$ conversion on $0.25 \mathrm{Fe} / \mathrm{HBEA}$ from Ref. [4], reaction conditions: $[\mathrm{NO}]=\left[\mathrm{NH}_{3}\right]=500 \mathrm{ppm},\left[\mathrm{O}_{2}\right]=5 \mathrm{vol} . \%$ and GHSV $=50000 \mathrm{~h}^{-1}$ ) and Cu/ZSM-5 (NO conversion on CuZSM-5-124-fresh from Ref. [25], reaction conditions: $[\mathrm{NO}]=\left[\mathrm{NH}_{3}\right]=500 \mathrm{ppm},\left[\mathrm{O}_{2}\right]=5 \mathrm{vol} . \%,\left[\mathrm{H}_{2} \mathrm{O}\right]=10 \mathrm{vol} . \%$ and GHSV $=100000 \mathrm{~h}^{-1}$ ).

the temperature for the $50 \% \mathrm{NO}_{x}$ conversion over $\mathrm{Fe}_{0.75} \mathrm{Mn}_{0.25} \mathrm{TiO}_{x}$ was ca. $50{ }^{\circ} \mathrm{C}$ lower than that over the traditional $\mathrm{V}_{2} \mathrm{O}_{5}-\mathrm{WO}_{3} / \mathrm{TiO}_{2}$ catalyst, making it possible to be utilized for the removal of $\mathrm{NO}_{x}$ from actual flue gas with low exhaust temperature. To fully compare the SCR activity of $\mathrm{Fe}_{0.75} \mathrm{Mn}_{0.25} \mathrm{TiO}_{x}$ with that of $\mathrm{Cu} / \mathrm{ZSM}-5$ reported by Park et al. [25], we also performed another activity test under the identical reaction conditions with those in literature, i.e. GHSV $=100000 \mathrm{~h}^{-1}$ and 10 vol. $\% \mathrm{H}_{2} \mathrm{O}$. Under the high GHSV and $\mathrm{H}_{2} \mathrm{O}$ concentration, the operation temperature window of $\mathrm{Fe}_{0.75} \mathrm{Mn}_{0.25} \mathrm{TiO}_{x}$ greatly shifted towards high temperature range, thus resulting in lower SCR activity below $300^{\circ} \mathrm{C}$ than that of $\mathrm{Cu} /$ ZSM-5. Therefore, GHSV is an important factor to be considered in catalyst design and the $\mathrm{H}_{2} \mathrm{O}$ durability of $\mathrm{Fe}_{0.75} \mathrm{Mn}_{0.25} \mathrm{TiO}_{x}$ still needs to be improved in our future work. Furthermore, the influences of GHSV and $\mathrm{O}_{2}$ concentration on $\mathrm{NO}_{x}$ conversions over $\mathrm{Fe}_{0.75} \mathrm{Mn}_{0.25}$ $\mathrm{TiO}_{x}$ were also investigated (Figs. S1 and S2 in Supporting Information). The $\mathrm{NO}_{x}$ conversions over this catalyst still could get $100 \%$ above $250{ }^{\circ} \mathrm{C}$ even at a high GHSV of $100000 \mathrm{~h}^{-1}$, which is beneficial to the actual industrial application. The influence of $\mathrm{O}_{2}$ on $\mathrm{NO}_{x}$ conversions was more obvious at low temperatures than that at 


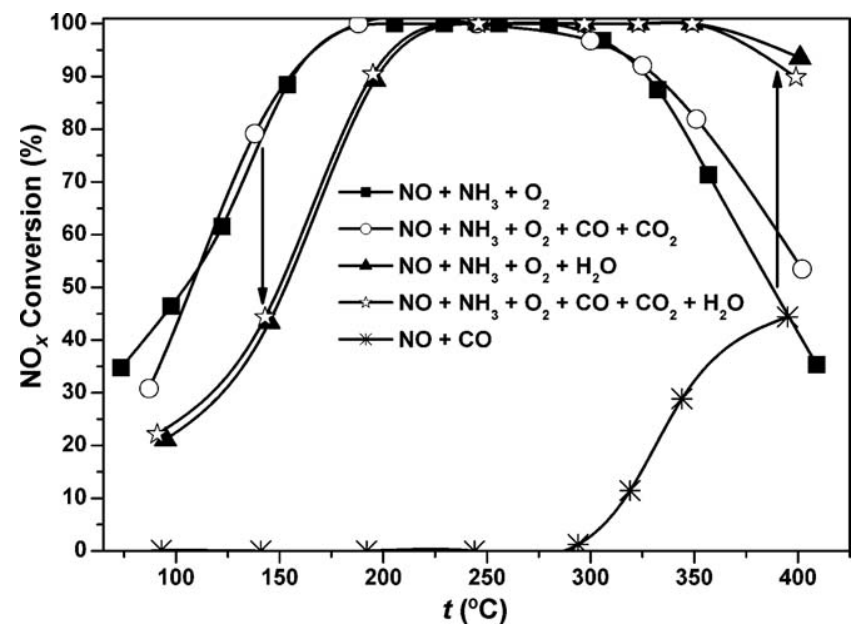

Fig. 3. Influence of $\mathrm{CO}, \mathrm{CO}_{2}$ and $\mathrm{H}_{2} \mathrm{O}$ on $\mathrm{NO}_{x}$ conversion in the $\mathrm{NH}_{3}-\mathrm{SCR}$ reaction over $\mathrm{Fe}_{0.75} \mathrm{Mn}_{0.25} \mathrm{TiO}_{x}$ catalyst. Reaction conditions: $[\mathrm{NO}]=\left[\mathrm{NH}_{3}\right]=500 \mathrm{ppm},\left[\mathrm{O}_{2}\right]=$ $5 \mathrm{vol} . \%,[\mathrm{CO}]=1000 \mathrm{ppm}$ ( when used), $\left[\mathrm{CO}_{2}\right]=5 \mathrm{vol} . \%$ (when used), $\left[\mathrm{H}_{2} \mathrm{O}\right]=5 \mathrm{vol} . \%$ (when used), $\mathrm{N}_{2}$ balance, total flow rate $500 \mathrm{ml} / \mathrm{min}$ and GHSV $=50000 \mathrm{~h}^{-1}$.

high temperatures, implying that different SCR reaction mechanisms might be followed in different temperature ranges, just as those over unsubstituted iron titanate catalyst [26].

\subsubsection{Influence of $\mathrm{CO}, \mathrm{CO}_{2}$ and $\mathrm{H}_{2} \mathrm{O}$ on the $\mathrm{SCR}$ activity}

For practical purposes, the $\mathrm{Fe}_{0.75} \mathrm{Mn}_{0.25} \mathrm{TiO}_{x}$ catalyst was also tested in the presence of $\mathrm{CO}, \mathrm{CO}_{2}$ and $\mathrm{H}_{2} \mathrm{O}$, and the results are shown in Fig. 3. As we can see, the existence of $\mathrm{CO}$ and $\mathrm{CO}_{2}$ in the feeding gas did not obviously influence the SCR activity below $200{ }^{\circ} \mathrm{C}$, which is similar as the results shown by Balle et al. [4]. However, the $\mathrm{NO}_{x}$ conversion above $300{ }^{\circ} \mathrm{C}$ showed a slight increase, probably due to the reduction of $\mathrm{NO}_{x}$ by $\mathrm{CO}$ when the unselective oxidation of $\mathrm{NH}_{3}$ severely happened at high temperatures: $2 \mathrm{CO}+2 \mathrm{NO} \rightarrow \mathrm{N}_{2}+2 \mathrm{CO}_{2}$. To confirm this speculation, additional experiment concerning the reaction between $\mathrm{NO}$ and $\mathrm{CO}$ was performed, during which partial NO was indeed reduced to $\mathrm{N}_{2}$ by CO above $300{ }^{\circ} \mathrm{C}$ (as shown in Fig. 3). On the other hand, the presence of $\mathrm{H}_{2} \mathrm{O}$ in the feeding gas significantly decreased the $\mathrm{NO}_{x}$ conversion below $200{ }^{\circ} \mathrm{C}$ mainly due to the blocking of active sites [4]. However, at temperatures above $300{ }^{\circ} \mathrm{C}$ the $\mathrm{NO}_{x}$ conversion showed an obvious increase, which was due to the inhibition effect of $\mathrm{H}_{2} \mathrm{O}$ on the unselective oxidation of $\mathrm{NH}_{3}$. This point of view could be verified by the decrease of $\mathrm{NH}_{3}$ conversion and enhancement of $\mathrm{N}_{2}$ selectivity in the SCR reaction over $\mathrm{Fe}_{0.75} \mathrm{Mn}_{0.25} \mathrm{TiO}_{x}$ in the presence of $\mathrm{H}_{2} \mathrm{O}$ (see Fig. S3 in Supporting Information). For the reaction condition containing $\mathrm{CO}, \mathrm{CO}_{2}$ and $\mathrm{H}_{2} \mathrm{O}$, the SCR activity was very similar as that in the presence of $\mathrm{H}_{2} \mathrm{O}$ alone, with the $\mathrm{NO}_{x}$ conversion keeping at 100\% from 200 to $350{ }^{\circ} \mathrm{C}$.

\subsection{4. $\mathrm{NO}$ and $\mathrm{NH}_{3}$ oxidation activities of $\mathrm{Fe}_{a} \mathrm{Mn}_{1-a} \mathrm{TiO}_{x}$ catalysts}

It was reported that the enhancement of $\mathrm{NO}$ oxidation to $\mathrm{NO}_{2}$ over SCR catalysts could significantly promote the low temperature activity due to the occurrence of the "fast SCR": $\mathrm{NO}+\mathrm{N}$ $\mathrm{O}_{2}+2 \mathrm{NH}_{3} \rightarrow 2 \mathrm{~N}_{2}+3 \mathrm{H}_{2} \mathrm{O}[16,27,28]$. The effect of $\mathrm{NO}_{2}$ and the detailed "fast SCR" reaction mechanism have been studied extensively over conventional $\mathrm{V}_{2} \mathrm{O}_{5}-\mathrm{WO}_{3} / \mathrm{TiO}_{2}$ and Fe-zeolite catalysts (such as Fe/HBEA and Fe/ZSM-5) by many researchers [4,29-33]. In this study, the effect of Mn substitution amounts on NO oxidation activity of iron titanate catalyst was also investigated and the results are shown in Fig. 4A. With the increasing of Mn substitution amounts the $\mathrm{NO}$ conversion to $\mathrm{NO}_{2}$ showed an obvious enhancement, and the maximum conversions were
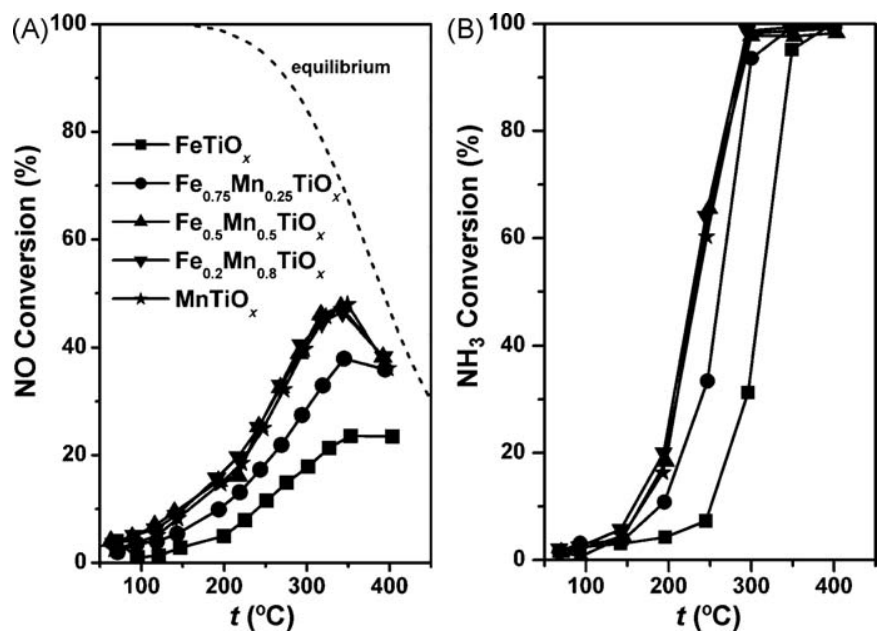

Fig. 4. (A) $\mathrm{NO}$ conversion in separate $\mathrm{NO}$ oxidation reaction and (B) $\mathrm{NH}_{3}$ conversion in separate $\mathrm{NH}_{3}$ oxidation reaction over $\mathrm{Fe}_{a} \mathrm{Mn}_{1-a} \mathrm{TiO}_{x}$ catalysts. Reaction conditions: $[\mathrm{NO}]=500 \mathrm{ppm}$ or $\left[\mathrm{NH}_{3}\right]=500 \mathrm{ppm},\left[\mathrm{O}_{2}\right]=5 \mathrm{vol} . \%, \mathrm{~N}_{2}$ balance, total flow rate $500 \mathrm{ml} / \mathrm{min}$ and $\mathrm{GHSV}=50000 \mathrm{~h}^{-1}$.

obtained when the substitution amount was above 0.5. Although the NO oxidation activities of $\mathrm{Fe}_{0.2} \mathrm{Mn}_{0.8} \mathrm{TiO}_{x}$ and $\mathrm{MnTiO}_{x}$ were much higher than that of $\mathrm{Fe}_{0.75} \mathrm{Mn}_{0.25} \mathrm{TiO}_{x}$, the SCR activities over the former two catalysts were still a little lower than that over the latter one, as shown in Fig. 2. This implies that the SCR activity over these catalysts is not only related with the NO oxidation activity, but also related with some other structural or redox properties, which will be discussed later in this paper.

Previous study by Roy et al. [17] showed that the $\mathrm{N}_{2}$ selectivity in the SCR reaction had a strong inverse correlation with the oxidation of $\mathrm{NH}_{3}$, therefore the separate $\mathrm{NH}_{3}$ oxidation experiments were also conducted over $\mathrm{Fe}_{a} \mathrm{Mn}_{1-a} \mathrm{TiO}_{x}$ catalysts. As shown in Fig. 4B, the $\mathrm{NH}_{3}$ conversions had an obvious enhancement with the increasing of Mn substitution amounts, and the highest $\mathrm{NH}_{3}$ conversions were obtained when the substitution amount was above 0.5 . However, the $\mathrm{N}_{2}$ selectivity showed an obvious decrease in $\mathrm{NH}_{3}$ oxidation reactions at the same time (see Fig. S4 in Supporting Information), which is in accordance with the changing trend of $\mathrm{N}_{2}$ selectivity in the SCR reactions. This implies that although the NO oxidation activity is enhanced when partial $\mathrm{Fe}$ is substituted by Mn which is beneficial to the promotion of SCR activity, the unselective oxidation of $\mathrm{NH}_{3}$ to $\mathrm{N}_{2} \mathrm{O}, \mathrm{NO}$ or $\mathrm{NO}_{2}$ in the SCR conditions is also enhanced, resulting in the production of a large amount of by-products. There should be a compromise of the SCR activity and $\mathrm{N}_{2}$ selectivity when we determine on the Mn substitution amount in practical application.

\subsection{Structural properties}

\subsection{1. $N_{2}$ physisorption}

Fig. 5A shows the pore size distributions of $\mathrm{Fe}_{a} \mathrm{Mn}_{1-a} \mathrm{TiO}_{x}$ catalysts derived from the desorption branches of $\mathrm{N}_{2}$ adsorptiondesorption isotherms. In the diameter range below $3 \mathrm{~nm}$, the $\mathrm{N}_{2}$ adsorbed volume per gram per $\mathrm{nm}$ increased in the following sequence: $\quad \mathrm{FeTiO}_{x}<\mathrm{MnTiO}_{x}<\mathrm{Fe}_{0.2} \mathrm{Mn}_{0.8} \mathrm{TiO}_{x}<\mathrm{Fe}_{0.75} \mathrm{Mn}_{0.25} \mathrm{TiO}_{x}$ $<\mathrm{Fe}_{0.5} \mathrm{Mn}_{0.5} \mathrm{TiO}_{x}$. This means that the $\mathrm{Fe}_{0.5} \mathrm{Mn}_{0.5} \mathrm{TiO}_{x}$ sample has the most abundant micropores or mesopores, which can supply more inner surface area for the occurrence of SCR reaction. The BET surface areas in Fig. 5B also followed such a sequence, which is in well harmony with the sequence of SCR activity. The results in Fig. 5C show that $\mathrm{Fe}_{0.5} \mathrm{Mn}_{0.5} \mathrm{TiO}_{x}$ possesses the largest pore volume due to the coexistence of iron and manganese species with the molar ratio of Fe:Mn being 1:1, which is beneficial to the enhancement of SCR 

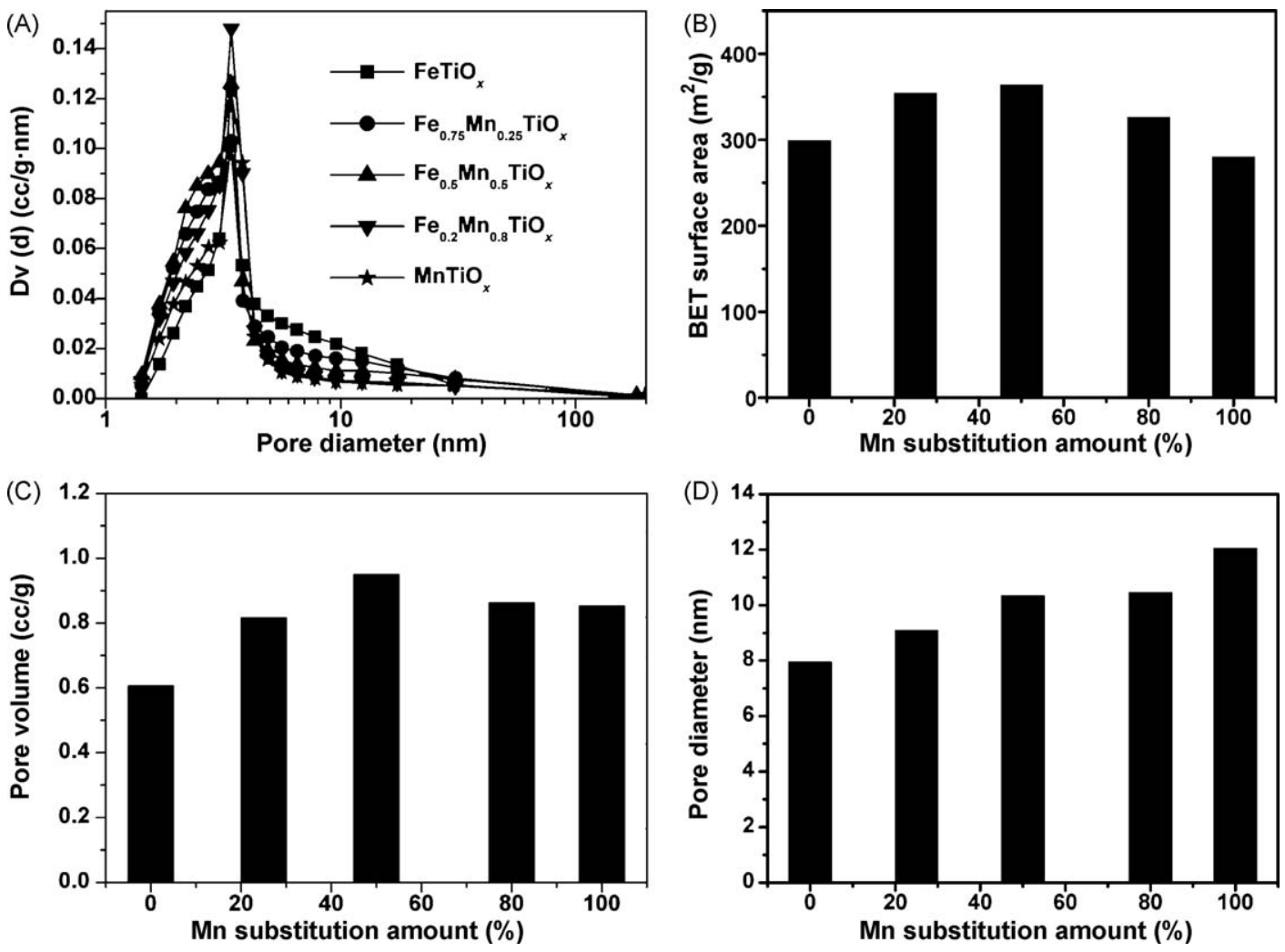

Fig. 5. $\mathrm{N}_{2}$ adsorption-desorption results of $\mathrm{Fe}_{a} \mathrm{Mn}_{1-a} \mathrm{TiO}_{x}$ catalysts: (A) pore size distributions; (B) BET surface areas; (C) pore volumes; (D) average pore diameters.

activity. With the increasing of Mn substitution amounts, the average pore diameter in Fig. 5D became larger, which might be one of the reasons for the activity decline over $\mathrm{Fe}_{0.2} \mathrm{Mn}_{0.8} \mathrm{TiO}_{x}$ and $\mathrm{MnTiO}_{x}$.

\subsection{2. $X R D$}

Fig. 6 shows the XRD results of $\mathrm{Fe}_{a} \mathrm{Mn}_{1-a} \mathrm{TiO}_{x}$ catalysts together with the standard cards of $\mathrm{FeTiO}_{3}, \mathrm{MnTiO}_{3}$ and $\mathrm{FeMnTiO}_{4}$ in JCPDS (vertical lines). All of the samples showed no obvious diffraction patterns besides some broad bumps, implying that all samples were in poor crystallization. The interaction between iron, manganese and titanium species led to a highly dispersive state of active phases, without forming iron oxides, manganese oxides or titanium oxide particles. In our previous study [5,6], we have concluded that the $\mathrm{FeTiO}_{x}$ catalyst was mainly in the form of crystallite phases of $\mathrm{Fe}_{2} \mathrm{TiO}_{5}$ and $\mathrm{FeTiO}_{3}$ with specific $\mathrm{Fe}-\mathrm{O}-\mathrm{Ti}$

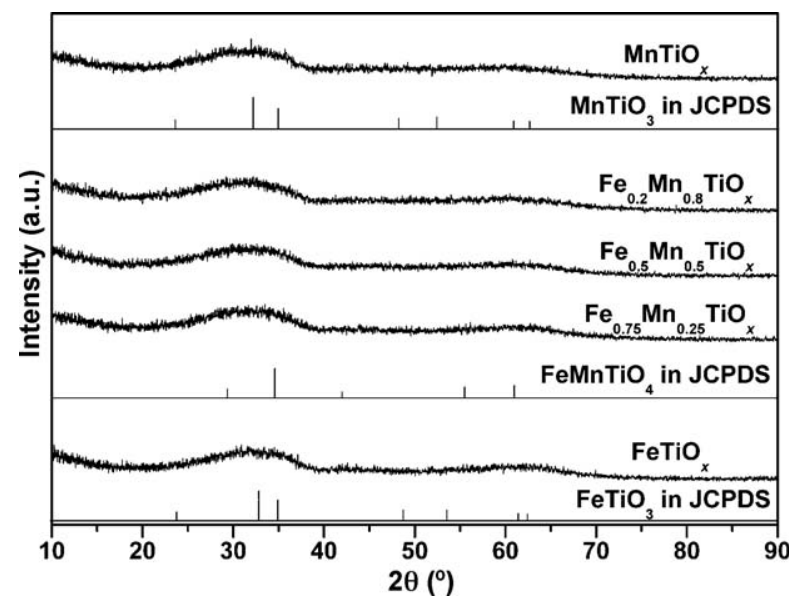

Fig. 6. XRD results of $\mathrm{Fe}_{a} \mathrm{Mn}_{1-a} \mathrm{TiO}_{x}$ catalysts and standard cards in JCPDS. structure which showed high SCR activity. The substitution of Fe by Mn did not destroy the crystallite structures; furthermore, some crystallites with $\mathrm{Mn}-\mathrm{O}-\mathrm{Ti}$ and $\mathrm{Fe}-\mathrm{O}-\mathrm{Mn}$ structures might also be formed, because either $\mathrm{FeMnTiO}_{4}$ or $\mathrm{MnTiO}_{3}$ also has some diffraction peaks in the positions of the broad bumps. The formation of new active phases might be another reason for the activity improvement.

\subsubsection{XAFS}

For our $\mathrm{Fe}_{a} \mathrm{Mn}_{1-a} \mathrm{TiO}_{x}$ catalysts in crystallite phases, XAFS is a suitable tool to characterize the structural information because it can be used to determine the local environment around specific atoms, irrespective of crystallinity or dimensionality of the target materials. Fig. 7A presents the normalized XANES of Fe-K-edge in Fe-containing catalysts. All samples showed characteristic preedge peaks at $7114 \mathrm{eV}$, which could be attributed to $1 \mathrm{~s}-3 \mathrm{~d}$ dipolar forbidden transition [34]. The peak position and the peak shape corresponded well with those of the ferric compounds in fourfold or fivefold coordination [35], indicating that the iron species in our catalysts was mainly in $\mathrm{Fe}^{3+}$ oxidation state. It is reported that this pre-edge peak will get additional intensity if the iron center is in a noncentral symmetric environment or through mixing of $3 \mathrm{~d}$ and $4 \mathrm{p}$ orbitals, which is caused by the breakdown of inversion symmetry because of the structure distortion (i.e. bond-angle disorder) [34,36]. As the XANES spectra in this study have been shifted vertically for comparison, we can directly read the pre-edge peak intensities by subtracting the base line values from the peak values. The inserted figure is the enlargement of the spectra region denoted by the dashed rectangle to better discriminate the preedge peak intensities. For $\mathrm{Fe}_{0.5} \mathrm{Mn}_{0.5} \mathrm{TiO}_{x}$ catalyst, the intensity of the pre-edge peak was largest, implying that when the molar ratio of Fe:Mn is $1: 1$, the interaction between these two species led to a severest structure distortion of $\mathrm{Fe}-\mathrm{O}$ coordination. Fig. 7C presents the normalized XANES of Mn-K-edge in Mn-containing catalysts and all samples showed characteristic pre-edge peaks at $6541 \mathrm{eV}$, 

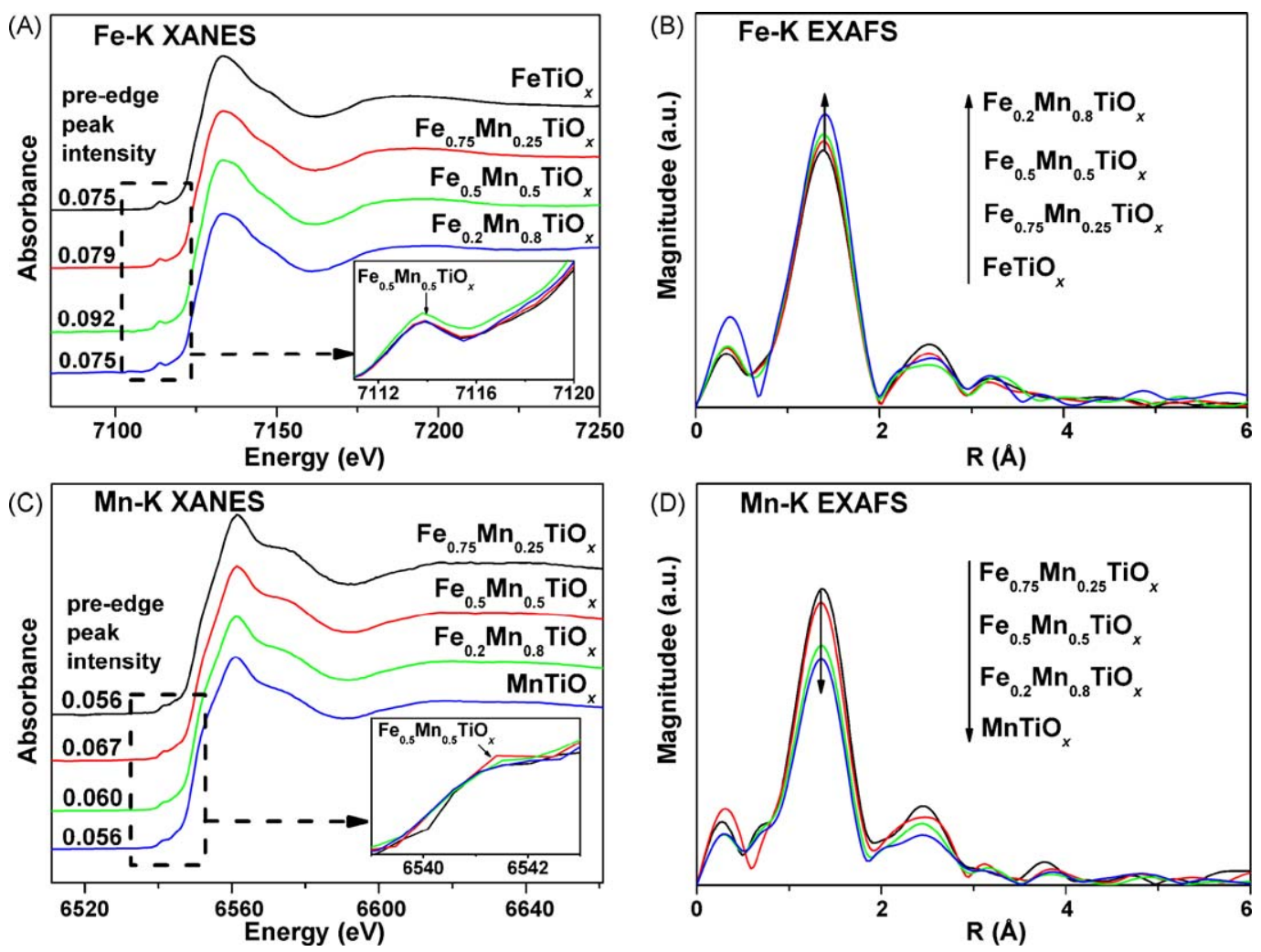

Fig. 7. (A) XANES, (B) FT-EXAFS results of Fe-K-edge and (C) XANES, (D) FT-EXAFS results of Mn-K-edge in $\mathrm{Fe}_{a} \mathrm{Mn}_{1-a} \mathrm{TiO}_{x}$ catalysts.

which could also be attributed to the crystal field transition from the core $1 \mathrm{~s}$ levels to the empty $3 \mathrm{~d}$ levels and more or less $4 \mathrm{p}$ hybridized by manganese ligands [37]. $\mathrm{Fe}_{0.5} \mathrm{Mn}_{0.5} \mathrm{TiO}_{x}$ catalyst also had the largest intensity of pre-edge peak which can be distinguished from the inserted figure, suggesting a severest structure distortion of $\mathrm{Mn}-\mathrm{O}$ coordination. It was reported that amorphous or crystallite materials with enormous structure distortion would provide more active sites for catalytic reactions than crystalline materials, which was probably responsible for the high catalytic activity. The amorphous $\mathrm{MnO}_{x}$ as electrocatalyst by Yang and $\mathrm{Xu}$ for oxygen reduction reaction is one of these examples [38]. Shishido et al. also concluded that the isolated and tetrahedrally coordinated iron sites with higher degree of structure distortion in the framework of Fe-MCM-41 were responsible for the high activity in oxidation reaction, while small iron oxide clusters with lower degree of structure distortion were not effective [39]. Therefore, we can deduce that the severest distortion of $\mathrm{Fe}-\mathrm{O}$ and $\mathrm{Mn}-\mathrm{O}$ coordination structure in our crystallite $\mathrm{Fe}_{0.5} \mathrm{Mn}_{0.5} \mathrm{TiO}_{x}$ catalyst is also an important reason for its highest SCR activity.

The radial distribution function ( $\mathrm{R}$ space, phase shift uncorrected) of Fe-K-edge and Mn-K-edge derived from the EXAFS data are shown in Fig. 7B and D, respectively. For Fe-K-edge, a peak centered at $1.41 \AA$ showed up, which could be attributed to the first Fe-O shell. No obvious peak above $2 \AA$ belonging to the second coordination shell was observed, indicating that all samples were in crystallite phase, which is in accordance with the XRD results. For Mn-K-edge, the situation was similar. Only one obvious peak at $1.35 \AA$ due to the first $\mathrm{Mn}-\mathrm{O}$ shell was observed, and the second coordination shell was not well crystallized, either. With the increasing of Mn substitution amounts, the peak intensity of Fe-O shell showed a monotonic increase, and at the same time the peak intensity of $\mathrm{Mn}-\mathrm{O}$ shell showed a monotonic decrease. If we assume that the coordination numbers of $\mathrm{Fe}-\mathrm{O}$ and $\mathrm{Mn}-\mathrm{O}$ shells do not change during the Mn substitution process, the peak intensity in $\mathrm{R}$ space will only be relevant with the structural disorder (i.e. bond-length disorder). Lower peak intensity indicates higher degree of structural disorder. It was reported that the more disordering of the structure, the higher catalytic activity would be obtained over catalysts for various reactions, such as over the $\mathrm{Cu}$ / $\mathrm{ZrO}_{2}$ catalyst for the steam reforming of methanol [40], the Ni-Co$\mathrm{B}$ amorphous catalyst for the hydrogenation of benzene [41] and the mixed $\mathrm{La}-\mathrm{Sr}-\mathrm{Co}-\mathrm{Fe}-\mathrm{O}$ perovskite catalyst for the $\mathrm{CO}$ oxidation [42]. Although no direct correlation between the structural disorder and catalytic activity over SCR catalysts was clearly proposed by other researchers, some experimental results from literature showed that this empirical conclusion might also be applicable to the catalysts for the SCR reaction. For example, the iron species in Fe/ZSM-5 with more distorted tetrahedrally coordinated structure showed higher activity than that with regular octahedrally coordinated structure in the catalytic reduction of NO with iso-butane [43]. Moreover, the zeolite encapsulated vanadium oxo species [44] and the highly isolated vanadium species in mesoporous $\mathrm{V}_{2} \mathrm{O}_{5}-\mathrm{TiO}_{2}-\mathrm{SiO}_{2}$ catalyst [45] with distorted tetrahedrally coordinated structure also showed high activity in the SCR of $\mathrm{NO}$ with $\mathrm{NH}_{3}$. In this study, both of the iron species and manganese species in our catalysts contributed to the SCR activity, and there was an inverse correlation between the structure distortion of Fe-O shell and $\mathrm{Mn}-\mathrm{O}$ shell during the $\mathrm{Mn}$ substitution process. Summarizing the results in Fig. 7B and D, $\mathrm{Fe}_{0.5} \mathrm{Mn}_{0.5} \mathrm{TiO}_{x}$ catalyst had the most appropriate structural disorder of these two active species, and this is another important reason for its highest SCR activity.

\subsection{Redox properties}

\subsubsection{XPS}

The XPS results of Fe 2p are shown in Fig. 8A. Two characteristic peaks ascribed to $\mathrm{Fe} 2 \mathrm{p}_{3 / 2}$ at $711.4 \mathrm{eV}$ and $\mathrm{Fe} 2 \mathrm{p}_{1 / 2}$ at $724.9 \mathrm{eV}$ appeared for each Fe-containing sample, indicating that the iron 

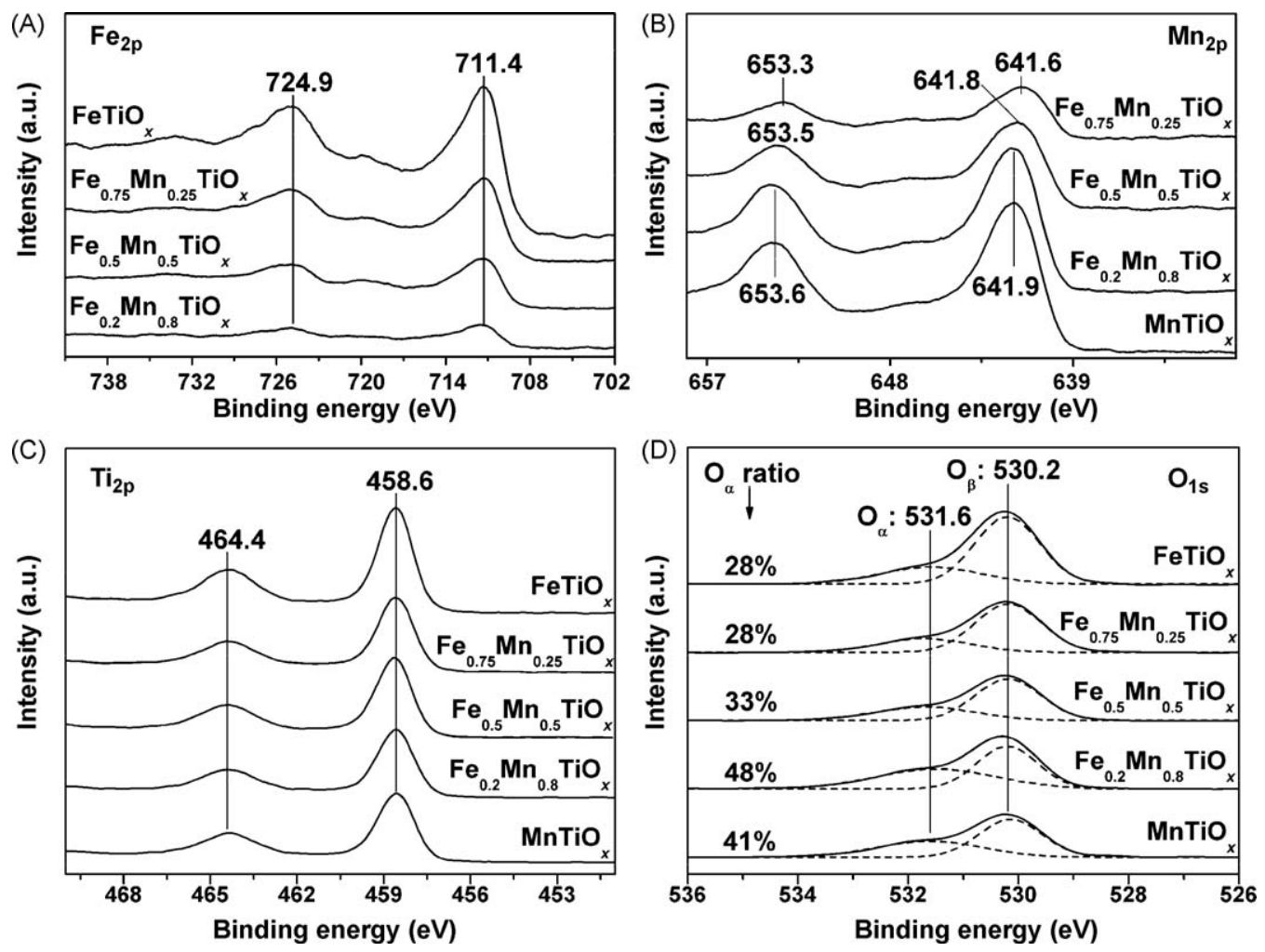

Fig. 8. XPS results of (A) Fe 2p, (B) Mn 2p, (C) Ti 2p and (D) O 1s in $\mathrm{Fe}_{a} \mathrm{Mn}_{1-a} \mathrm{TiO}_{x}$ catalysts.

species in these samples was in $\mathrm{Fe}^{3+}$ oxidation state [46]. It was reported in our previous study that the iron species in iron titanate catalyst possessed higher binding energies than that in pristine $\mathrm{Fe}_{2} \mathrm{O}_{3}$ due to the strong interaction between iron and titanium species [6], and the substitution of partial Fe by Mn did not change this situation. The iron species with enhanced oxidative ability than that in $\mathrm{Fe}_{2} \mathrm{O}_{3}$ was still responsible for the high SCR activity. With the increasing of Mn substitution amounts, the intensities of Fe $2 \mathrm{p}_{3 / 2}$ and $\mathrm{Fe} 2 \mathrm{p}_{1 / 2}$ peaks gradually decreased owing to the concentration reduction of surface iron species. However, the corresponding binding energies did not show variation, implying that the differences of SCR, $\mathrm{NO}$ oxidation and $\mathrm{NH}_{3}$ oxidation activities over these catalysts were not caused by the redox ability change of iron species.

The XPS results of Mn 2p in Mn-containing samples are shown in Fig. 8B. For $\mathrm{Fe}_{0.75} \mathrm{Mn}_{0.25} \mathrm{TiO}_{x}$ catalyst with low Mn substitution amount, the binding energies of $\mathrm{Mn} 2 \mathrm{p}_{3 / 2}$ and $\mathrm{Mn} 2 \mathrm{p}_{1 / 2}$ peaks were located at 641.6 and $653.3 \mathrm{eV}$, respectively, which indicated that the majority of manganese species in this sample was in $\mathrm{Mn}^{3+}$ oxidation state, similar as that in $\mathrm{Mn}_{2} \mathrm{O}_{3}[47,48]$. Besides, a small fraction of manganese species in this sample was in $\mathrm{Mn}^{4+}$ oxidation state, thus the overall manganese species in $\mathrm{Fe}_{0.75} \mathrm{Mn}_{0.25} \mathrm{TiO}_{x}$ showed a little higher binding energies than those in $\mathrm{Mn}_{2} \mathrm{O}_{3}$ which was reported in literature $\left(\mathrm{Mn} 2 \mathrm{p}_{3 / 2}\right.$ at $641.2 \pm 0.2 \mathrm{eV}$ ) [47]. With the increasing of Mn substitution amounts, the intensities of $M n 2 p_{3 / 2}$ and $\mathrm{Mn} 2 \mathrm{p}_{1 / 2}$ peaks gradually enhanced due to the concentration increase of surface manganese species. At the same time, the corresponding binding energies also showed variation, with Mn $2 \mathrm{p}_{3 / 2}$ shifting from 641.6 to $641.9 \mathrm{eV}$ and $\mathrm{Mn} 2 \mathrm{p}_{1 / 2}$ shifting from 653.3 to $653.6 \mathrm{eV}$. This result showed that the $\mathrm{Mn}^{4+} / \mathrm{Mn}^{3+}$ ratio in $\mathrm{Fe}_{a} \mathrm{Mn}_{1-a} \mathrm{TiO}_{x}$ serial catalysts became larger when the Mn substitution amount was higher. With the increasing of $\mathrm{Mn}^{4+} / \mathrm{Mn}^{3+}$ ratio, the oxidation of $\mathrm{NO}$ to $\mathrm{NO}_{2}$ would get enhanced, which was beneficial to promote the low temperature SCR activity [49]. This is in accordance with the NO oxidation results in Fig. 4A. At the same time, the unselective oxidation of $\mathrm{NH}_{3}$ would also get enhanced with the increasing of $\mathrm{Mn}^{4+} / \mathrm{Mn}^{3+}$ ratio resulting in low $\mathrm{N}_{2}$ selectivity in the SCR reaction, which was caused by the higher degree of hydrogen abstraction from ammonia by manganese species with higher oxidation state [7]. This is in accordance with the $\mathrm{NH}_{3}$ oxidation results in Fig. 4B and Fig. S4.

Fig. $8 \mathrm{C}$ shows the XPS results of Ti $2 \mathrm{p}$ in all catalysts. For each sample, two characteristic peaks attributed to Ti $2 \mathrm{p}_{3 / 2}$ at $458.6 \mathrm{eV}$ and $\mathrm{Ti} 2 \mathrm{p}_{1 / 2}$ at $464.4 \mathrm{eV}$ showed up, indicating the presence of $\mathrm{Ti}^{4+}$ [50]. As the XPS results shown in our previous study [6], the binding energies of Ti $2 \mathrm{p}_{3 / 2}$ and $\mathrm{Ti} 2 \mathrm{p}_{1 / 2}$ in $\mathrm{FeTiO}_{x}$ were smaller than those in pristine $\mathrm{TiO}_{2}$ due to the strong interaction between iron and titanium species. This phenomenon was probably caused by the deviation of electronic cloud from $\mathrm{Fe}^{3+}$ to $\mathrm{Ti}^{4+}$, because $\mathrm{Ti}^{4+}$ shows stronger affinity of electrons comparing with that of $\mathrm{Fe}^{3+}$. Similar phenomenon was also observed on other iron-titanium oxide composites prepared by other researchers [51,52]. In this study, the introduction of manganese species did not influence the redox behavior of titanium species, because the Ti $2 \mathrm{p}$ peak positions showed no obvious change with the increasing of Mn substitution amounts.

Summarizing the XPS results of Fe 2p, Mn 2p and Ti 2p, we can conclude that the enhanced oxidative ability of $\mathrm{Fe}_{a} \mathrm{Mn}_{1-a} \mathrm{TiO}_{x}$ catalysts was mainly caused by the introduction of $\mathrm{Mn}$, which showed higher oxidation state when the substitution amount was larger. We can infer that the adsorption of $\mathrm{NO}_{x}$ over these catalysts will get enhanced due to the higher surface concentration and stronger oxidative ability of manganese species. This point of view will be verified in the following experimental sections concerning $\mathrm{NO}_{x}$ adsorption abilities.

As the XPS results shown in Fig. 8D, the 01 s peak was fitted into two peaks by searching for the optimum combination of Gaussian bands with the correlation coefficients $\left(r^{2}\right)$ above 0.99 . The peak at $530.2 \mathrm{eV}$ corresponds to the lattice oxygen $\mathrm{O}^{2-}$ (denoted as $\mathrm{O}_{\beta}$ ), and the one at $531.6 \mathrm{eV}$ corresponds to the surface adsorbed 
oxygen (denoted as $\mathrm{O}_{\alpha}$ ) such as $\mathrm{O}_{2}{ }^{2-}$ or $\mathrm{O}^{-}$belonging to defectoxide or hydroxyl-like group [49,53]. The surface chemisorbed oxygen $\mathrm{O}_{\alpha}$ was reported to be highly active in oxidation reaction due to its higher mobility than lattice oxygen $\mathrm{O}_{\beta}[53,54]$, and the high relative concentration ratio of $\mathrm{O}_{\alpha} /\left(\mathrm{O}_{\alpha}+\mathrm{O}_{\beta}\right)$ on catalyst surface could be correlated with high SCR activity [49]. After the Fe was substituted by $\mathrm{Mn}$, the $\mathrm{O}_{\alpha} /\left(\mathrm{O}_{\alpha}+\mathrm{O}_{\beta}\right)$ ratio had an obvious increase, especially at high Mn substitution amounts. This implies that comparing with $\mathrm{FeTiO}_{x}$, there are more oxide defects or hydroxyl-like groups in Mn-containing catalysts. On one hand, the oxide defects can adsorb and activate gaseous $\mathrm{O}_{2}$ to form active oxygen species, which is beneficial to promote the NO oxidation to $\mathrm{NO}_{2}$ and thus the "fast SCR" process. On the other hand, the $\mathrm{NH}_{3}$ adsorption in the form of $\mathrm{NH}_{4}{ }^{+}$can also be enhanced due to the production of larger amount of surface hydroxyl groups, which act as Brønsted acid sites. The formed $\mathrm{NH}_{4}^{+}$can react with adsorbed $\mathrm{NO}_{2}$ to produce active intermediate species, and then further react with gaseous $\mathrm{NO}$ to produce $\mathrm{N}_{2}$ and $\mathrm{H}_{2} \mathrm{O}[26,55,56]$. The enhancement of $\mathrm{NO}_{x}$ and $\mathrm{NH}_{3}$ adsorption over $\mathrm{Mn}$ substituted catalysts will be discussed later.

\subsection{2. $\mathrm{H}_{2}-\mathrm{TPR}$}

The above XPS results of $\mathrm{O} 1 \mathrm{~s}$ could supply some information about the surface chemisorbed oxygen $\mathrm{O}_{\alpha}$ over these catalysts, and the $\mathrm{H}_{2}$-TPR results could supply some information about the total reducible oxygen including $\mathrm{O}_{\alpha}$ and partial $\mathrm{O}_{\beta}$. All $\mathrm{H}_{2}$ consumption peaks shown in Fig. 9 could be attributed to the reduction of iron and manganese species, because the pristine $\mathrm{TiO}_{2}$ sample showed no reduction peaks during the whole temperature range that we investigated $[6,9]$.

In our previous study, we have concluded that the reduction of iron species in $\mathrm{FeTiO}_{x}$ followed a two step process: $\mathrm{Fe}^{3+}-\mathrm{O}-$ $\mathrm{Ti} \rightarrow \mathrm{Fe}^{2+/ 3+}-\mathrm{O}-\mathrm{Ti} \rightarrow \mathrm{Fe}^{2+}-\mathrm{O}-\mathrm{Ti}[6]$ with a $T_{\max }$ peak locating at $414{ }^{\circ} \mathrm{C}$. After Mn substitution, the reduction process of iron species did not change, and the whole TPR profiles of $\mathrm{Fe}_{a} \mathrm{Mn}_{1-a} \mathrm{TiO}_{x}$ catalysts were composed of Fe and Mn reduction peaks. With the increasing of $\mathrm{Mn}$ substitution amounts, a low temperature reduction peak $\left(T_{1}\right)$ between 350 and $400{ }^{\circ} \mathrm{C}$ showed up, which must be caused by the reduction of manganese species. This means that the oxygen mobility was greatly enhanced due to the introduction of $\mathrm{Mn}$, which was beneficial to the SCR reaction. $\mathrm{Fe}_{0.5} \mathrm{Mn}_{0.5} \mathrm{TiO}_{x}$ exhibited the lowest temperature of $T_{1}$ peak at $352{ }^{\circ} \mathrm{C}$ and this in harmony with its highest SCR activity. For $\mathrm{Fe}_{0.2} \mathrm{Mn}_{0.8} \mathrm{TiO}_{x}$ and $\mathrm{MnTiO}_{x}$ samples with higher Mn substitution amounts, another two well defined reduction peaks locating at relative high temperatures also emerged $\left(T_{2}\right.$ at 480 or $544{ }^{\circ} \mathrm{C}, T_{3}$ at

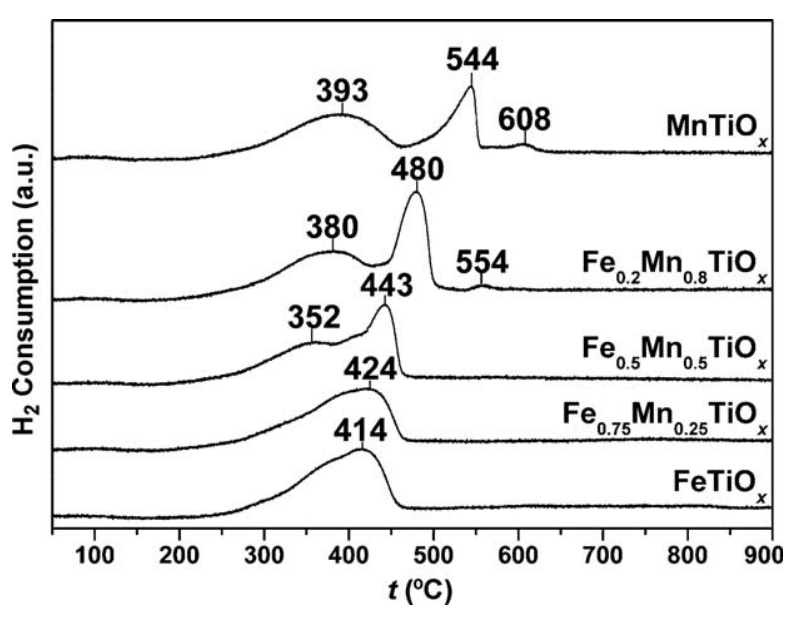

Fig. 9. $\mathrm{H}_{2}$-TPR profiles of $\mathrm{Fe}_{a} \mathrm{Mn}_{1-a} \mathrm{TiO}_{x}$ catalysts.
554 or $608^{\circ} \mathrm{C}$ ). Previous studies [9,57] showed that the reduction of pristine $\mathrm{MnO}_{x}$ or $\mathrm{MnO}_{x} / \mathrm{TiO}_{2}$ samples followed a two step process $\mathrm{MnO}_{2} \rightarrow \mathrm{Mn}_{2} \mathrm{O}_{3} \rightarrow \mathrm{MnO}$ or a three step process $\mathrm{MnO}_{2} \rightarrow \mathrm{Mn}_{2} \mathrm{O}_{3} \rightarrow \mathrm{Mn}_{3} \mathrm{O}_{4} \rightarrow \mathrm{MnO}$, during which the area ratio of $\mathrm{H}_{2}$ consumption peaks should be $1: 1$ or $3: 1: 2$. However, the reduction process of our $\mathrm{MnTiO}_{x}$ sample was not similar as either of these. The area ratio of $T_{1} /\left(T_{2}+T_{3}\right)$ was calculated to be nearly $2: 1$, which implied that the $T_{1}$ reduction peak was due to $\mathrm{Mn}^{4+}-\mathrm{O}_{x^{-}}$ $\mathrm{Ti} \rightarrow \mathrm{Mn}^{3+/ 2+}-\mathrm{O}_{x}-\mathrm{Ti}$. Herein, the manganese species in $\mathrm{Mn}^{3+/ 2+}-$ $\mathrm{O}_{x}-\mathrm{Ti}$ intermediate had similar oxidation state as that in $\mathrm{Mn}_{3} \mathrm{O}_{4}$. Both of the $T_{2}$ and $T_{3}$ reduction peaks were ascribed to $\mathrm{Mn}^{3+/ 2+}-\mathrm{O}_{x^{-}}$ $\mathrm{Ti} \rightarrow \mathrm{Mn}^{2+}-\mathrm{O}_{x}-\mathrm{Ti}$, because further reduction to metallic $\mathrm{Mn}^{0}$ does not proceed until over $1200{ }^{\circ} \mathrm{C}$ [58]. Over the Mn-MCM-41 sample prepared by Reddy et al., the $\mathrm{Mn}^{4+}$ species was also only reduced to $\mathrm{Mn}^{2+}$ by $\mathrm{H}_{2}$ at around $600{ }^{\circ} \mathrm{C}[59]$. Therefore, in our $\mathrm{MnTiO}_{x}$ sample after the $T_{2}$ reduction peak the majority of manganese species was in $\mathrm{Mn}^{2+}$ state, resulting in the formation of analogous pyrophanite $\left(\mathrm{Mn}^{2+} \mathrm{TiO}_{3}\right)$ compound in the presence of $\mathrm{Ti}^{4+}$ species. This pyrophanite compound would possibly be sintered to form compact oxide layer on the catalyst surface and make it difficult for the gaseous $\mathrm{H}_{2}$ to diffuse into the inner bulk phase, thus leading to the delayed appearance of the small $T_{3}$ reduction peak. The total reduction process of $\mathrm{MnTiO}_{x}$ is similar as the results over $\mathrm{MnO}_{x}$ or $\mathrm{MnO}_{x} / \mathrm{Al}_{2} \mathrm{O}_{3}$ in previous studies [7,60,61]. Moreover, it is noteworthy that the $T_{2}$ peak in $\mathrm{MnTiO}_{x}$ delayed ca. $60{ }^{\circ} \mathrm{C}$ than that over $\mathrm{Fe}_{0.2} \mathrm{Mn}_{0.8} \mathrm{TiO}_{x}$ and ca. $100{ }^{\circ} \mathrm{C}$ than that over $\mathrm{Fe}_{0.5} \mathrm{Mn}_{0.5}$ $\mathrm{TiO}_{x}$, which was mainly due to the absence of iron species. During the reduction process of iron and manganese containing catalysts, a small fraction of iron species was firstly reduced to metallic $\mathrm{Fe}^{\mathrm{O}}$ nanoparticles, which could dissociate $\mathrm{H}_{2}$ into $\mathrm{H}$ atoms; in the presence of the in situ formed water vapor, the dissociated $\mathrm{H}$ atoms could be transferred effectively to further reduce the manganese oxides through the so-called H-spillover effect [62-64]. This Hspillover effect could significantly lower the reduction temperature of $T_{2}$ peak, which was a new feature introduced by the coexistence of iron and manganese species.

\section{4. $\mathrm{NH}_{3}$ and $\mathrm{NO}_{x}$ adsorption abilities}

\subsection{1. $\mathrm{NH}_{3}-\mathrm{TPD}$ and $\mathrm{NO}_{x}-\mathrm{TPD}$}

Fig. 10A shows the $\mathrm{NH}_{3}$-TPD results over $\mathrm{Fe}_{a} \mathrm{Mn}_{1-a} \mathrm{TiO}_{x}$ catalysts using the fragments of $m / z=16\left(\mathrm{NH}_{2}\right)$ and $m / z=15$ (NH) to identify $\mathrm{NH}_{3}$ due to the disturbance of $m / z=17$ by $\mathrm{H}_{2} \mathrm{O}$. In the temperature range from 30 to $500{ }^{\circ} \mathrm{C}$, all of the samples showed three $\mathrm{NH}_{3}$ desorption peaks. Comparing with the in situ DRIFTS results of $\mathrm{NH}_{3}$-TPD in Fig. S5, we can assign these three peaks as
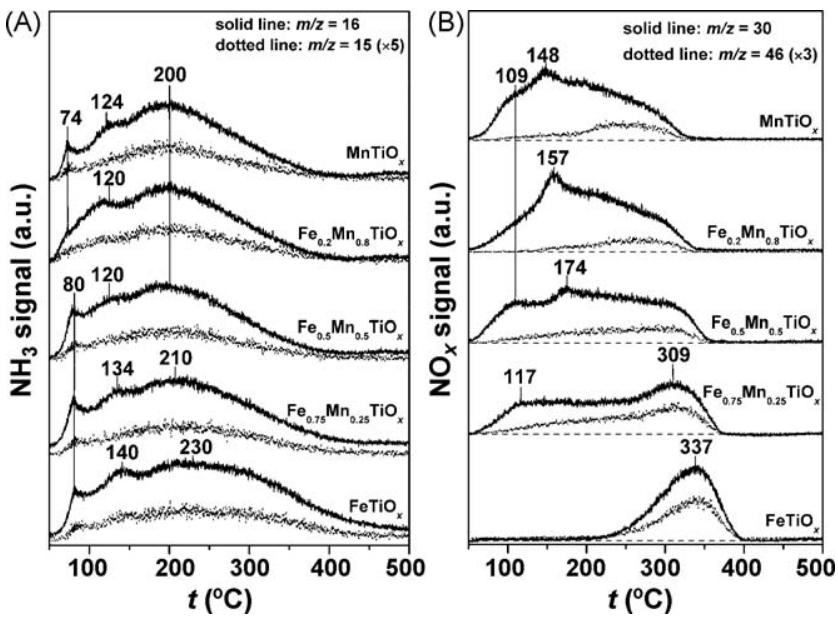

Fig. 10. TPD profiles of (A) $\mathrm{NH}_{3}$ and (B) $\mathrm{NO}_{x}$ over $\mathrm{Fe}_{a} \mathrm{Mn}_{1-a} \mathrm{TiO}_{x}$ catalysts. 
follows: the small sharp peaks below $100{ }^{\circ} \mathrm{C}$ were caused by the desorption of physisorbed $\mathrm{NH}_{3}$; the medium-sized peaks between 120 and $140{ }^{\circ} \mathrm{C}$ were caused by the desorption of $\mathrm{NH}_{4}{ }^{+}$weakly bound to surface hydroxyls; and the broadest peaks centered at $200-230{ }^{\circ} \mathrm{C}$ were caused by the desorption of coordinated $\mathrm{NH}_{3}$ bound to Lewis acid sites and residual $\mathrm{NH}_{4}{ }^{+}$strongly bound to surface hydroxyls with enhanced acidity by sulfate species (from $\mathrm{Ti}\left(\mathrm{SO}_{4}\right)_{2}$ precursor). Besides all the desorption peaks slightly moved to the low temperature edge, it seemed that the Mn substitution of Fe did not obviously influence the $\mathrm{NH}_{3}$ adsorption ability of these catalysts, especially the adsorption amount. This result implied in an opposite way that $\mathrm{NH}_{3}$ also mainly adsorbed on titanium sites over Mn substituted catalysts, similar as the situation that we described in previous study over $\mathrm{FeTiO}_{x}$ catalyst [26]. The detailed relationship between surface adsorbed $\mathrm{NH}_{3}$ species and SCR activity will be discussed in the following section.

The $\mathrm{NO}_{x}$-TPD results over $\mathrm{Fe}_{a} \mathrm{Mn}_{1-a} \mathrm{TiO}_{x}$ catalysts are shown in Fig. 10B. Different from the $\mathrm{NH}_{3}$-TPD results, the $\mathrm{NO}_{x}$ desorption profiles exhibited obvious change when partial Fe was substituted by $\mathrm{Mn}$. Over unsubstituted $\mathrm{FeTiO}_{x}$ catalyst, only one obvious $\mathrm{NO}_{x}$ desorption band centered at $337^{\circ} \mathrm{C}$ showed up. With the increasing of $\mathrm{Mn}$ substitution amounts, there was a larger proportion of $\mathrm{NO}_{x}$ desorption from 100 to $300{ }^{\circ} \mathrm{C}$. Comparing with the in situ DRIFTS results of $\mathrm{NO}_{x}$-TPD in Fig. S6, we can have the peak assignments as follows: the peaks below $120^{\circ} \mathrm{C}$ could be attributed to physisorbed $\mathrm{NO}_{x}$; the peaks centered between 140 and $175{ }^{\circ} \mathrm{C}$ were due to the decomposition of monodentate nitrate species; and the broad peaks above $175{ }^{\circ} \mathrm{C}$ were due to the decomposition of bridging nitrate species and bidentate nitrate species with higher thermal stability. The dotted lines representing the fragment of desorbed $\mathrm{NO}_{2}(m / z=46)$ also confirmed this point of view. The introduction of $\mathrm{Mn}$ resulted in the enhanced NO oxidation to $\mathrm{NO}_{2}$ and thus the enhanced adsorption of $\mathrm{NO}_{x}$ as nitrate species at lower temperatures. This means that comparing with the unsubstituted catalyst, more nitrate species on catalyst surface could participate in the SCR reaction in the temperature range that we investigated, which was beneficial to promote the SCR activity.

\subsubsection{In situ DRIFTS of $\mathrm{NH}_{3}$ and $\mathrm{NO}_{x}$ adsorption}

The in situ DRIFTS results of $\mathrm{NH}_{3}$ adsorption at $30{ }^{\circ} \mathrm{C}$ are shown in Fig. 11A. Over all samples, a weak and broad band centered at $1805 \mathrm{~cm}^{-1}$ was observed with similar intensity, which was difficult to be assigned due to the lack of literature support. Similar weak bands around $1800 \mathrm{~cm}^{-1}$ were also found on $\mathrm{Fe}-$ $\mathrm{TiO}_{2}$-PILC catalyst after $\mathrm{NH}_{3}$ adsorption at room temperature in Long and Yang's work [65]; however, they did not assign these bands probably due to the low surface concentration of these species. Considering the in situ DRIFTS results of $\mathrm{NH}_{3}$-TPD in Fig. S5 and $\mathrm{NH}_{3}$-TPD results in Fig. 10A, these $\mathrm{NH}_{3}$ species showed rather low thermal stability and disappeared at ca. $100{ }^{\circ} \mathrm{C}$, which might be ascribed to physisorbed $\mathrm{NH}_{3}$. Over the catalyst surface with large surface area and strong acidity, these physisorbed $\mathrm{NH}_{3}$ molecules might form ammonia clusters $\left(\left[\mathrm{NH}_{3}\right]_{n}\right)$ through the effect of hydrogen bonding in which $\mathrm{N}$ acted as electron couple donator and $\mathrm{H}$ from another $\mathrm{NH}_{3}$ molecule nearby acted as electron couple receptor, thus exhibiting higher vibration frequency than that of gas phase $\mathrm{NH}_{3}$. With the increasing of Mn substitution amounts in $\mathrm{Fe}_{a} \mathrm{Mn}_{1-a} \mathrm{TiO}_{x}$ serial catalysts, the bands attributed to $\mathrm{NH}_{4}{ }^{+}\left(\delta_{\mathrm{s}}\right.$ at $1676 \mathrm{~cm}^{-1}$ and $\delta_{\text {as }}$ at $1458 \mathrm{~cm}^{-1}$ ) [65-67] showed an obvious increase in intensity. The bands at 3020 and $2806 \mathrm{~cm}^{-1}$ attributed to $\mathrm{N}-\mathrm{H}$ stretching vibration modes of $\mathrm{NH}_{4}^{+}$[66] also showed progressive increase in intensity. At the same time, the intensities of the negative bands at 3732 and $3676 \mathrm{~cm}^{-1}$ ascribed to $\mathrm{O}-\mathrm{H}$ stretching vibration modes due to the interaction of surface hydroxyls with $\mathrm{NH}_{3}$ also became larger during this Mn substitution
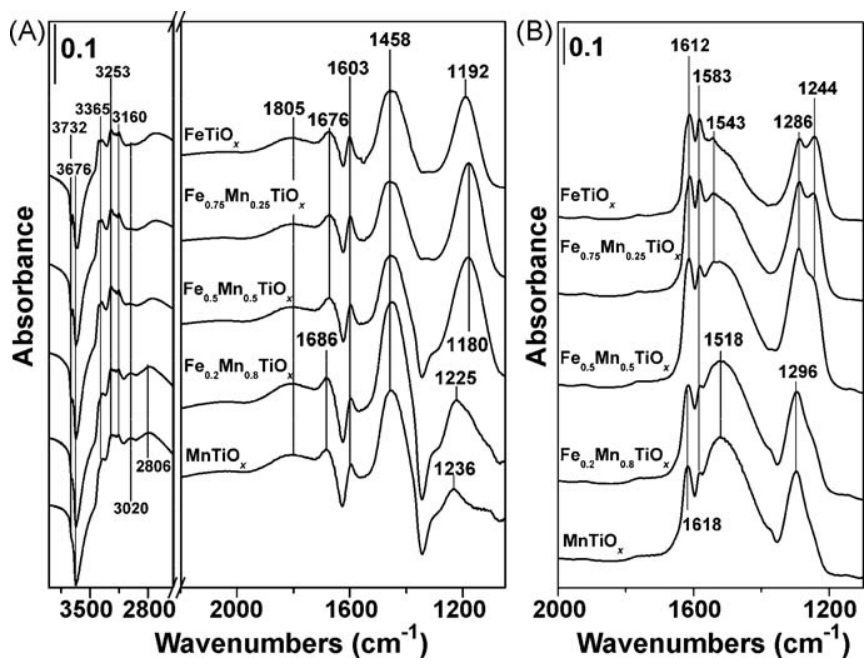

Fig. 11. In situ DRIFTS results of (A) $\mathrm{NH}_{3}$ adsorption and (B) $\mathrm{NO}+\mathrm{O}_{2}$ adsorption over $\mathrm{Fe}_{a} \mathrm{Mn}_{1-a} \mathrm{TiO}_{x}$ catalysts at $30^{\circ} \mathrm{C}$.

process. This means that the introduction of Mn resulted in more Brønsted acid sites on the catalyst surface, which was favorable for the promotion of SCR activity. Schwidder et al. [68] also proposed a promoting effect of Brønsted acidity on the low temperature SCR activity over iron-based catalyst probably via an acid-catalyzed decomposition of active intermediate. The possible reason for the Brønsted acidity enhancement in this study might be that more residual sulfate species from $\mathrm{Ti}\left(\mathrm{SO}_{4}\right)_{2}$ precursor was left on the catalyst surface due to higher coordination ability of $\mathrm{Mn}^{4+}$ than that of $\mathrm{Fe}^{3+}$. This point of view can be verified by the intensity increase of negative band around $1344 \mathrm{~cm}^{-1}$ attributed to the coverage of residual sulfate species $\left(v_{\text {as }}=0\right.$ ) [65] by adsorbed $\mathrm{NH}_{3}$ with the increasing of Mn substitution amounts. For coordinated $\mathrm{NH}_{3}$ bound to Lewis acid sites ( $\delta_{\text {as }}$ at 1603 and $\delta_{\mathrm{s}}$ at $1192 \mathrm{~cm}^{-1}$ ), the band intensity firstly had an obvious increase, and then showed an intense decrease when the substitution amount was higher than 0.5 . The bands at 3365,3253 and $3160 \mathrm{~cm}^{-1}$ ascribed to $\mathrm{N}-\mathrm{H}$ stretching vibration modes of coordinated $\mathrm{NH}_{3}$ [66] also followed similar trend. It was reported that both ionic $\mathrm{NH}_{4}{ }^{+}$and coordinated $\mathrm{NH}_{3}$ could take part in the SCR process through reaction with $\mathrm{NO}_{2}$ adsorbed species to form active intermediates [55]. Therefore, the proper proportion of Brønsted acid sites and Lewis acid sites over $\mathrm{Fe}_{0.5} \mathrm{Mn}_{0.5} \mathrm{TiO}_{x}$ catalyst was responsible for its highest SCR activity.

Fig. $11 \mathrm{~B}$ presents the in situ DRIFTS results of $\mathrm{NO}_{x}$ adsorption at $30^{\circ} \mathrm{C}$. With the increasing of Mn substitution amounts, the bands attributed to bridging nitrate species ( $\nu_{3}$ high at 1612 or $1618 \mathrm{~cm}^{-1}$ and $\nu_{3}$ low at $1244 \mathrm{~cm}^{-1}$ ) and bidentate nitrate species ( $v_{3}$ high at $1583 \mathrm{~cm}^{-1}$ ) [69] showed no obvious change, except that the band at $1244 \mathrm{~cm}^{-1}$ in $\mathrm{Fe}_{0.2} \mathrm{Mn}_{0.8} \mathrm{TiO}_{x}$ and $\mathrm{MnTiO}_{x}$ was strongly overlapped by other growing nitrate species. This monotonously growing species was ascribed to monodentate nitrate $\left(v_{3}\right.$ high at 1543 or $1518 \mathrm{~cm}^{-1}$ and $v_{3}$ low at 1286 or $1296 \mathrm{~cm}^{-1}$ ) [69], which was thought to be the real reactive species in the SCR condition [26]. The higher $\mathrm{Mn}$ substitution amounts resulted in the enhancement of $\mathrm{NO}$ oxidation to $\mathrm{NO}_{2}$, and thus the production of more monodentate nitrate species $\mathrm{M}-\mathrm{O}-\mathrm{NO}_{2}(\mathrm{M}=\mathrm{Fe}$ and $\mathrm{Mn})$, which was similar as the $\mathrm{NO}_{2}$ adsorbed species in the previous study by Long and Yang [55]. In the SCR reaction condition, this M$\mathrm{O}-\mathrm{NO}_{2}$ species could rapidly react with adjacent adsorbed $\mathrm{NH}_{4}{ }^{+}$or $\mathrm{NH}_{3}$ to produce more reactive intermediates $\mathrm{M}-\mathrm{O}-\mathrm{NO}_{2}\left[\mathrm{NH}_{4}^{+}\right]_{2}$ or $\mathrm{M}-\mathrm{O}-\mathrm{NO}_{2}\left[\mathrm{NH}_{3}\right]_{2}$, which could further react with gaseous NO to form $\mathrm{N}_{2}$ and $\mathrm{H}_{2} \mathrm{O}$ [55]. This reaction mechanism is very similar as the one proposed by other researchers, in which the reduction of ammonium nitrate by NO is an important step [30,32]. The in situ 


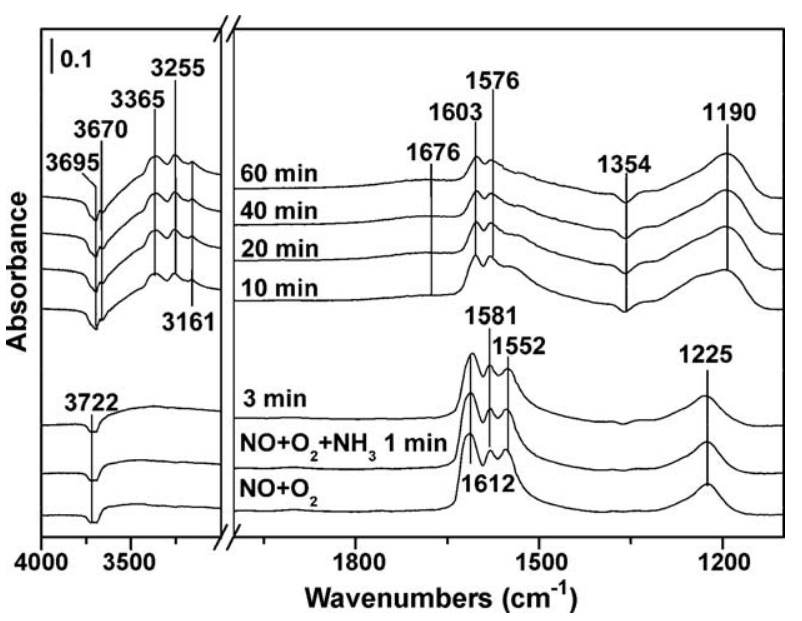

Fig. 12. In situ DRIFTS results of SCR reaction over $\mathrm{Fe}_{0.75} \mathrm{Mn}_{0.25} \mathrm{TiO}_{x}$ catalyst at $200{ }^{\circ} \mathrm{C}$, during which $\mathrm{NO}+\mathrm{O}_{2}$ was let in firstly and $\mathrm{NH}_{3}$ was let in subsequently.

DRIFTS result of SCR reaction over $\mathrm{Fe}_{0.75} \mathrm{Mn}_{0.25} \mathrm{TiO}_{x}$ in Fig. 12 also showed that the monodentate nitrate species $\left(1552 \mathrm{~cm}^{-1}\right)$ could not be detected on the catalyst surface due to its high reactivity. Under the SCR reaction condition at $200{ }^{\circ} \mathrm{C}$, only $\mathrm{NH}_{3}$ adsorbed species (ionic $\mathrm{NH}_{4}{ }^{+}$at $1676 \mathrm{~cm}^{-1}$ and coordinated $\mathrm{NH}_{3}$ at 1603 and $\left.1190 \mathrm{~cm}^{-1}\right)$ and inert bidentate nitrate species $\left(1576 \mathrm{~cm}^{-1}\right)$ existed on the surface stably, implying the rapid consumption of reactive intermediates. Summarizing the in situ DRIFTS results of $\mathrm{NH}_{3} / \mathrm{NO}_{x}$ adsorption in Fig. 11 and the SCR reaction in Fig. 12, on the $\mathrm{Fe}_{0.5} \mathrm{Mn}_{0.5} \mathrm{TiO}_{x}$ catalyst the amount of $\mathrm{NH}_{4}{ }^{+}$and $\mathrm{NH}_{3}$ was the most abundant, and the formation of reactive monodentate nitrate species was also greatly enhanced. Therefore, it was reasonable to obtain the highest SCR activity over this catalyst.

\section{Conclusions}

The substitution of partial Fe by Mn could significantly promote the SCR activity of iron titanate catalyst, especially in the low temperature range. $\mathrm{Fe}_{0.5} \mathrm{Mn}_{0.5} \mathrm{TiO}_{x}$ with the molar ratio of Fe:Mn $=1: 1$ showed the best activity, over which $\mathrm{NO}_{x}$ was totally eliminated at $175{ }^{\circ} \mathrm{C}$ at $\mathrm{GHSV}=50000 \mathrm{~h}^{-1}$. However, the $\mathrm{N}_{2}$ selectivity showed an obvious decrease with the increasing of Mn substitution amounts, and there should be a compromise between the SCR activity and $\mathrm{N}_{2}$ selectivity when we determine on the Mn substitution amount in practical industrial application.

The active phases in Mn substituted catalysts were still in crystallite states, similar as those in iron titanate catalyst. The strong interaction of iron, manganese and titanium species in $\mathrm{Fe}_{0.5} \mathrm{Mn}_{0.5} \mathrm{TiO}_{x}$ resulted in the largest surface area and porosity, the severest structural distortion and most appropriate structural disorder, the enhanced oxidative ability of manganese species, the highest mobility of lattice oxygen, the proper ratio of Brønsted acid sites and Lewis acid sites together with the enhanced $\mathrm{NO}_{x}$ adsorption capacity, which were all responsible for its highest SCR activity. Studies concerning the SCR reaction mechanism, origin of $\mathrm{N}_{2} \mathrm{O}$ by-product and $\mathrm{H}_{2} \mathrm{O} / \mathrm{SO}_{2}$ inhibition effect over $\mathrm{Mn}$ substituted catalyst are under way.

\section{Acknowledgements}

We sincerely appreciate the help from National Synchrotron Radiation Laboratory, University of Science and Technology of China for supplying the beam time to carry out XAFS experiments. This work was financially supported by Chinese Academy of Sciences (KZCX1-YW-06-04) and the National High Technology
Research and Development Program of China (2006AA06A304, 2009AA06Z301).

\section{Appendix A. Supplementary data}

Supplementary data associated with this article can be found, in the online version, at doi:10.1016/j.apcatb.2009.09.029.

\section{References}

[1] H. Bosch, F. Janssen, Catal. Today 2 (1988) 369.

[2] G. Busca, L. Lietti, G. Ramis, F. Berti, Appl. Catal. B: Environ. 18 (1998) 1.

[3] J.P. Dunn, P.R. Koppula, H.G. Stenger, I.E. Wachs, Appl. Catal. B: Environ. 19 (1998) 103.

[4] P. Balle, B. Geiger, S. Kureti, Appl. Catal. B: Environ. 85 (2009) 109.

[5] F. Liu, H. He, C. Zhang, Chem. Commun. (2008) 2043.

[6] F. Liu, H. He, C. Zhang, Z. Feng, L. Zheng, Y. Xie, T. Hu, Appl. Catal. B: Environ., submitted for publication.

[7] F. Kapteijn, L. Singoredjo, A. Andreini, J.A. Moulijn, Appl. Catal. B: Environ. 3 (1994) 173.

[8] X. Tang, J. Hao, W. Xu, J. Li, Catal. Commun. 8 (2007) 329.

[9] P.R. Ettireddy, N. Ettireddy, S. Mamedov, P. Boolchand, P.G. Smirniotis, Appl. Catal. B: Environ. 76 (2007) 123.

[10] Z. Wu, B. Jiang, Y. Liu, Appl. Catal. B: Environ. 79 (2008) 347.

[11] P.G. Smirniotis, P.M. Sreekanth, D.A. Peña, R.G. Jenkins, Ind. Eng. Chem. Res. 45 (2006) 6436.

[12] T. Grzybek, J. Pasel, H. Papp, Phys. Chem. Chem. Phys. 1 (1999) 341.

[13] G. Qi, R.T. Yang, R. Chang, Appl. Catal. B: Environ. 51 (2004) 93.

[14] F. Eigenmann, M. Maciejewski, A. Baiker, Appl. Catal. B: Environ. 62 (2006) 311.

[15] M. Kang, E.D. Park, J.M. Kim, J.E. Yie, Catal. Today 111 (2006) 236

[16] G. Qi, R.T. Yang, Appl. Catal. B: Environ. 44 (2003) 217.

[17] S. Roy, B. Viswanath, M.S. Hegde, G. Madras, J. Phys. Chem. C 112 (2008) 6002.

[18] G. Qi, R.T. Yang, R. Chang, S. Cardoso, R.A. Smith, Appl. Catal. A: Gen. 275 (2004) 207.

[19] G. Carja, G. Delahay, C. Signorile, B. Coq, Chem. Commun. (2004) 1404.

[20] M. Casanova, E. Rocchini, A. Trovarelli, K. Schermanz, I. Begsteiger, J. Alloys Compd. 408-412 (2006) 1108

[21] S. Kieger, G. Delahay, B. Coq, Appl. Catal. B: Environ. 25 (2000) 1.

[22] X. Wang, T. Zhang, X. Sun, W. Guan, D. Liang, L. Lin, Appl. Catal. B: Environ. 24 (2000) 169.

[23] K.V. Klementev, J. Phys. D: Appl. Phys. 34 (2001) 209.

[24] R.Q. Long, R.T. Yang, J. Catal. 188 (1999) 332.

[25] J.-H. Park, H.J. Park, J.H. Baik, I.S. Nam, C.-H. Shin, J.-H. Lee, B.K. Cho, S.H. Oh, J. Catal. 240 (2006) 47.

[26] F. Liu, H. He, C. Zhang, Appl. Catal. B: Environ., submitted for publication.

[27] G. Madia, M. Koebel, M. Elsener, A. Wokaun, Ind. Eng. Chem. Res. 41 (2002) 3512.

[28] R.Q. Long, R.T. Yang, J. Catal. 198 (2001) 20.

[29] C. Ciardelli, I. Nova, E. Tronconi, D. Chatterjee, B. Bandl-Konrad, M. Weibel, B. Krutzsch, Appl. Catal. B: Environ. 70 (2007) 80.

[30] M. Devadas, O. Kröcher, M. Elsener, A. Wokaun, N. Söger, M. Pfeifer, Y. Demel, L. Mussmann, Appl. Catal. B: Environ. 67 (2006) 187.

[31] M. Koebel, G. Madia, M. Elsener, Catal. Today 73 (2002) 239.

[32] A. Grossale, I. Nova, E. Tronconi, D. Chatterjee, M. Weibel, J. Catal. 256 (2008) 312.

[33] M. Schwidder, S. Heikens, A. De Toni, S. Geisler, M. Berndt, A. Brückner, W. Grünert, J. Catal. 259 (2008) 96.

[34] Y. Wang, Q. Zhang, T. Shishido, K. Takehira, J. Catal. 209 (2002) 186.

[35] P.-E. Petit, F. Farges, M. Wilke, V.A. Solé, J. Synchrotron Radiat. 8 (2001) 952.

[36] T. Kawabata, N. Fujisaki, T. Shishido, K. Nomura, T. Sano, K. Takehira, J. Mol. Catal. A: Chem. 253 (2006) 279.

[37] E. Chalmin, F. Farges, G.E. Brown Jr., Contrib. Mineral. Petrol. 157 (2009) 111

[38] J. Yang, J.J. Xu, Electrochem. Commun. 5 (2003) 306.

[39] T. Shishido, Q. Zhang, Y. Wang, T. Tanaka, K. Takehira, Phys. Scripta T115 (2005) 762.

[40] A. Szizybalski, F. Girgsdies, A. Rabis, Y. Wang, M. Niederberger, T. Ressler, J. Catal. 233 (2005) 297

[41] B. Shen, S. Wei, K. Fang, J.F. Deng, Appl. Phys. A 65 (1997) 295.

[42] L.A. Isupova, V.A. Sadykov, S.V. Tsybulya, G.N. Kryukova, V.P. Ivanov, A.N. Petrov, O.F. Kononchuk, React. Kinet. Catal. Lett. 62 (1997) 129.

[43] M.S. Batista, M. Wallau, E.A. Urquieta-González, Braz. J. Chem. Eng. 22 (2005) 341.

[44] R.C. Adams, L. Xu, K. Moller, T. Bein, W.N. Delgass, Catal. Today 33 (1997) 263.

[45] V.I. Pârvulescu, S. Boghosian, V. Pârvulescu, S.M. Jung, P. Grange, J. Catal. 217 (2003) 172.

[46] T. Grzybek, J. Klinik, B. Buczek, Surf. Interface Anal. 23 (1995) 815.

[47] D.A. Peña, B.S. Uphade, P.G. Smirniotis, J. Catal. 221 (2004) 421.

[48] J. Li, J. Chen, R. Ke, C. Luo, J. Hao, Catal. Commun. 8 (2007) 1896

[49] M. Kang, E.D. Park, J.M. Kim, J.E. Yie, Appl. Catal. A: Gen. 327 (2007) 261

[50] S. Yuan, Q. Sheng, J. Zhang, H. Yamashita, D. He, Micropor. Mesopor. Mater. 110 (2008) 501.

[51] N. Perkas, O. Palchik, I. Brukental, I. Nowik, Y. Gofer, Y. Koltypin, A. Gedanken, J. Phys. Chem. B 107 (2003) 8772.

[52] A. Glisenti, J. Mol. Catal. A: Chem. 153 (2000) 169.

[53] Z. Wu, R. Jin, Y. Liu, H. Wang, Catal. Commun. 9 (2008) 2217. 
[54] H. Chen, A. Sayari, A. Adnot, F. Larachi, Appl. Catal. B: Environ. 32 (2001) 195.

[55] R.Q. Long, R.T. Yang, J. Catal. 190 (2000) 22.

[56] Z. Wu, B. Jiang, Y. Liu, H. Wang, R. Jin, Environ. Sci. Technol. 41 (2007) 5812.

[57] A. Khan, P.G. Smirniotis, J. Mol. Catal. A: Chem. 280 (2008) 43.

[58] J. Carnö, M. Ferrandon, E. Björnbom, S. Järås, Appl. Catal. A: Gen. 155 (1997) 265.

[59] E.P. Reddy, B. Sun, P.G. Smirniotis, J. Phys. Chem. B 108 (2004) 17198.

[60] X. Tang, Y. Li, X. Huang, Y. Xu, H. Zhu, J. Wang, W. Shen, Appl. Catal. B: Environ. 62 (2006) 265.

[61] M.C. Álvarez-Galván, V.A. de la Peña O’Shea, J.L.G. Fierro, P.L. Arias, Catal. Commun. 4 (2003) 223.
[62] O.J. Wimmers, P. Arnoldy, J.A. Moulijn, J. Phys. Chem. 90 (1986) 1331

[63] R.P. Viswanath, B. Viswanathan, M.V.C. Sastri, React. Kinet. Catal. Lett. 2 (1975) 51

[64] W.K. Jozwiak, E. Kaczmarek, T.P. Maniecki, W. Ignaczak, W. Maniukiewicz, Appl. Catal. A: Gen. 326 (2007) 17.

65] R.Q. Long, R.T. Yang, J. Catal. 186 (1999) 254

[66] N.Y. Topsøe, Science 265 (1994) 1217.

[67] G. Ramis, L. Yi, G. Busca, Catal. Today 28 (1996) 373.

[68] M. Schwidder, M.S. Kumar, U. Bentrup, J. Pérez-Ramírez, A. Brückner, W. Grünert, Micropor. Mesopor. Mater. 111 (2008) 124.

[69] G.M. Underwood, T.M. Miller, V.H. Grassian, J. Phys. Chem. A 103 (1999) 6184. 